Enterprise Advisory Services, Inc.

EASI 97-1

NPRC Endangered Species and Cultural

Resources Program

\title{
ENDANGERED SPECIES AND
}

\section{CULTURAL RESOURCES PROGRAM}

NAVAL PETROLEUM RESERVES IN

\section{CALIFORNIA}

\section{ANNUAL REPORT FY96}





\section{DISCLAIMER}

This report was prepared as an account of work sponsored by an agency of the United States Government. Neither the United States Government nor any agency thereof, nor any of their employees, makes any warranty, expressed or implied, or assumes any legal liability or responsibility for the accuracy, completeness, or usefulness of any information, apparatus, product, or process disclosed, or represents that its use would not infringe privately owned rights. Reference herein to any specific commercial product, product, or service by trade name, trademark, manufacturer, or otherwise, does not necessarily constitute or imply its endorsement, recommendation, or favoring by the United States Government or any agency thereof. The views and opinions of authors expressed herein do not necessarily state or reflect those of the United States Government of any agency thereof.

This report has been reproduced directly from the best available copy.

Available to DOE and DOE contractors from the Office of Scientific and Technical Information, P. O. Box 62, Oak Ridge, TN 37831; prices available from (615) 576-8401.

Available to the public from the National Technical Information Service, U. S. Department of Commerce, 5285 Port Royal Road, Springfield, VA 22161. 



\section{EXECUTIVE SUMMARY}

In FY96, Enterprise Advisory Services, Inc. (EASI) continued to support efforts to protect endangered species and cultural resources at the Naval Petroleum Reserves in California (NPRC). These efforts are conducted to ensure NPRC compliance with regulations regarding the protection of listed species and cultural resources on federal properties.

Population monitoring activities were conducted for San Joaquin kit foxes, giant kangaroo rats, blunt-nosed leopard lizards, and Hoover's wooly-star. Kit fox abundance and distribution was assessed by live-trapping over a $329-\mathrm{km}^{2}$ area. Kit fox reproduction and mortality were assessed by radiocollaring and monitoring 22 adults and two pups. Reproductive success and litter size were determined through live-trapping and den observations. Rates and sources of kit fox mortality were assessed by recovering dead radiocollared kit foxes and conducting necropsies to determine cause of death. Abundance of coyotes and bobcats, which compete with kit foxes, was determined by conducting scent station surveys. Kit fox diet was assessed through analysis of fecal samples collected from live-trapped foxes. Abundance of potential prey for kit foxes was determined by conducting transect surveys for lagomorphs and live-trapping small mammals.

Giant kangaroo rats and blunt-nosed leopard lizards were monitored using methodologies that are consistent with those employed by other researchers to facilitate comparisons of results. Giant kangaroo rat abundance and demographics were assessed by live-trapping in spring and late summer on a monitoring plot, and by monitoring the size of selected giant kangaroo rat colonies. Blunt-nosed leopard lizard population trends are tracked on two monitoring plots. Surveys were conducted in spring for adult lizards and in late summer for juvenile lizards. Hoover's wooly-star populations were assessed at six monitoring sites. Also, the effort to survey NPRC for rare plants continued in FY96. Full-coverage transect surveys were conducted on 648 ha. Numerous additional populations of Hoover's wooly-star were located along with several new populations of oil neststraw.

To mitigate impacts of oil field activities on listed species, 1,596 preactivity surveys covering approximately 639 ha were conducted in FY96. Mitigation measures implemented as a result of survey findings prevented incidental takes of listed species during construction activities. EASI also assisted with mitigating effects from third-party projects, primarily by conducting biological and cultural resource consultations with regulatory agencies. Cultural resource support provided to NPRC consisted primarily of conducting preliminary surveys for cultural resources, and finalizing a draft Cultural Resource Management Plan and Programmatic Agreement for Naval Petroleum Reserve No. 1 (NPR-1). EASI also provided endangered species and cultural resources compliance support for the 3-D seismic survey initiated on NPR-1. Activities conducted in support of this project included biological monitoring, coordinating a survey for cultural resources, and environmental awareness training. EASI will continue to support this project until its completion in FY97. 
The Endangered Species and Cultural Resources Program has conducted an applied habitat reclamation program at NPRC since 1985 . No active reclamation was conducted in FY96, but reclamation success was monitored on 66 sites reclaimed in 1986.

An investigation of factors influencing the distribution and abundance of kit foxes at NPRC continued in FY96. Factors being examined include habitat disturbance, topography, grazing, coyote abundance, lagomorph abundance, and shrub density. A manuscript on this topic is in preparation and will be completed in FY97. Also, a report evaluating the effects of a well blowout on plant and animal populations was completed. This report will be finalized and distributed in FY97. Finally, a conservation plan for protected species on NPR-1 was completed and also will be distributed in FY97.

In FY96, EASI continued to assist NPRC with environmental compliance documentation. Support was provided in two formal Section 7 consultations with the U.S. Fish and Wildlife Service (FWS) for continuing oil and gas operations on NPR-1 and Naval Petroleum Reserve No. 2 (NPR-2). Additional formal and informal consultations were conducted for third-party projects.

EASI also engaged in a number of outreach activities. Technical outreach included participation at several scientific meetings, four papers presented at conferences, completion of several scientific manuscripts and technical reports, and significant progress on several on-going or new manuscripts and reports. Other technical outreach included reports on progress at quarterly Endangered Species Advisory Committee meetings, presentations of results at an annual program review attended by approximately 85 individuals from government and private organizations, and participation in regional conservation efforts such as recovery planning meetings, Kern County Valley Floor Habitat Conservation Plan meetings, and Lokern Natural Area management meetings. Educational outreach activities included the preparation of numerous articles for the Elk Hills Weekly, on-site tours, presentations to students, visits to classrooms, Project WILD training, and participation in the annual Elk Hills Earth Day celebration, Coles Levee Ecosystem Preserve educational program, Derricks-to-Desks program, and Department of Energy Science Bowl.

In FY97, the focus of the NPRC Endangered Species and Cultural Resources Program will be somewhat different compared to previous years. This altered focus is in response to changes in compliance requirements, changes in sponsor needs, and the proposal by the Federal government to sell NPR-1 to private interests. The most significant difference will be a reduction in population monitoring activities. Specifically, kit fox population monitoring will be limited to the $117-\mathrm{km}^{2}$ NPR-1 study area. Kit fox reproduction and mortality will no longer be monitored. Also, monitoring activities will no longer be conducted for lagomorphs, small mammals, and predators. Another difference is that no new field studies will be initiated due to funding limitations and uncertainty regarding the sale of NPR-1. A final difference is that there will be a greater emphasis on analyzing existing data and preparing manuscripts. Analysis and dissemination of scientific data will contribute to both on-site and regional conservation efforts. 


\section{DISCLAMIER}

Portions of this document may be illegible in electronic image products. Inages are produced from the best available original document. 



\section{ACKNOWLEDGMENTS}

The NPRC Endangered Species and Cultural Resources Program is funded by the U.S. Department of Energy and Chevron USA, Inc.

Permission to conduct research on endangered and threatened species was granted by the U.S. Fish and Wildlife Service through permit PRT-683011, and a Memorandum of Understanding between the California Department of Fish and Game and Enterprise Advisory Services, Inc.

This is a continuing program and interpretation of facts contained in this report may change as new data are acquired and analyzed. Results should not be cited without prior consultation. 


\section{CONTENTS}

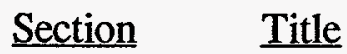

Page

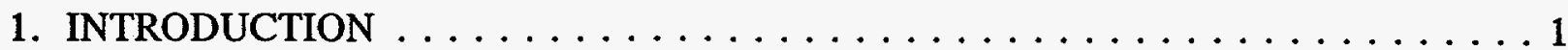

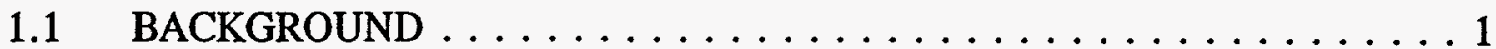

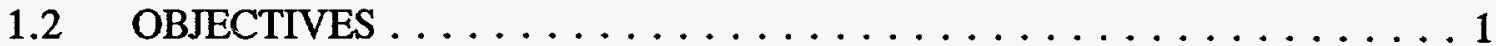

2. ENDANGERED SPECIES MONITORING PROGRAM . . . . . . . . . . . 3

2.1 MONITOR POPULATIONS OF SAN JOAQUIN KIT FOXES ON NPRC . . 3

2.2 MONITOR REPRODUCTION AND MORTALITY OF KIT FOXES $\ldots . .66$

2.3 MONITOR TRENDS OF CARNIVORE ABUNDANCE $\ldots \ldots \ldots \ldots$

2.4 MONITOR LAGOMORPH POPULATIONS . . . . . . . . . . . . 9

2.5 MONITOR SMALL MAMMAL POPULATIONS $\ldots \ldots \ldots \ldots \ldots$

2.6 DETERMINE DIET OF KIT FOXES $\ldots \ldots \ldots \ldots \ldots \ldots \ldots \ldots$

2.7 GIANT KANGAROO RAT POPULATION MONITORING . . . . . . . . 18

2.8 BLUNT-NOSED LEOPARD LIZARD POPULATION MONITORING . . . 22

2.9 HOOVER'S WOOLY-STAR POPULATION MONITORING . . . . . . . 24

2.10 ASSESSMENT OF SPECIAL STATUS PLANT SPECIES . . . . . . . . . 27

3. CONDUCT PREACTIVITY SURVEYS FOR NPRC PROJECTS . . . . . . . . . 33

3.1 CONDUCT ENDANGERED SPECIES AND CULTURAL RESOURCE

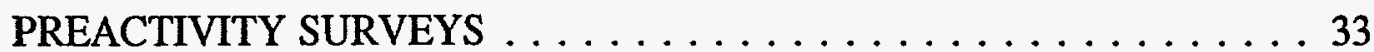

3.2 THIRD-PARTY PROJECTS $\ldots \ldots \ldots \ldots \ldots \ldots \ldots \ldots \ldots \ldots$

3.3 CULTURAL RESOURCES SUPPORT $\ldots \ldots \ldots \ldots \ldots \ldots \ldots$

3.4 WESTERN NPR-1 3-D SEISMIC PROGRAM . . . . . . . . . . . 37

4. HABITAT RECLAMATION AND MANAGEMENT $\ldots \ldots \ldots \ldots \ldots \ldots$

4.1 MONITORING RECLAMATION SUCCESS $\ldots \ldots \ldots \ldots \ldots$ 
Section

5. RESEARCH AND DEVELOPMENT $\ldots \ldots \ldots \ldots \ldots \ldots \ldots \ldots \ldots \ldots$

5.1 FACTORS INFLUENCING THE DISTRIBUTION AND ABUNDANCE OF KIT FOXES ON NPRC $\ldots \ldots \ldots \ldots \ldots \ldots \ldots \ldots \ldots$

5.2 CONSERVATION PLAN FOR PROTECTED SPECIES ON NPR-1 $\ldots 50$

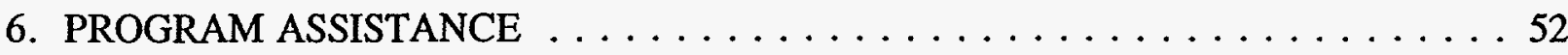

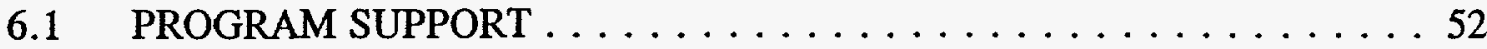

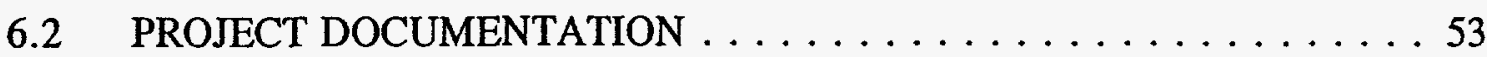

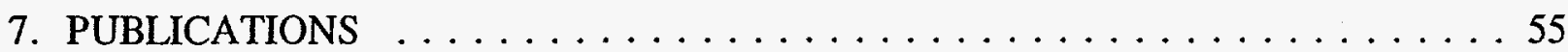




\section{TABLES}

Table

Title

Page

1. Number of trap-nights, total captures, and individual San Joaquin kit foxes captured during winter live-trapping sessions, Naval Petroleum Reserve No. 1 study area, 1981-1995, and Naval Petroleum Reserve No. 2, 1983-1995,

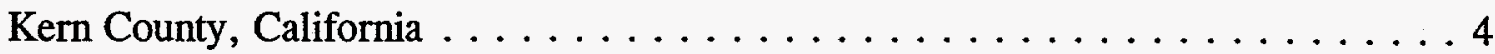

2. Small mammal captures and diversity indices within four physiographic regions on Naval Petroleum Reserve No. 1, Kern County, California, 1996

3. Mean percent cover and mean herbaceous production estimated in four physiographic regions on Naval Petroleum Reserve No. 1, Kern County, California, $1996 \ldots \ldots \ldots \ldots \ldots$. . . . . . . . . . . . . . . 14

4. Annual comparison of small mammal capture rates, vegetative cover and production, and small mammal diversity indices on Naval Petroleum Reserve No. 1, Kern County, California, 1993-1996 . . . . . . . . . . . . . . . . 14

5. Frequency of occurrence (\%) of items found in San Joaquin kit fox scat, Naval Petroleum Reserves in California, Kern County, California, 1996

6. Small mammal captures on the giant kangaroo rat plot, Naval Petroleum Reserves in California, Kern County, California, 1994-1996

7. Mean percent cover and mean herbaceous production estimated on the giant kangaroo rat monitoring plot, Naval Petroleum Reserve No. 1, Kern County, California, $1995-1996$. . . . . . . . . . . . . . . . . . . . . 20

8. Number of active giant kangaroo rat precincts in colonies monitored from Naval Petroleum Reserves in California, Kern County, California, 1993-1996 . . . . . . 21

9. Mean percent cover estimated on the blunt-nosed leopard lizard plots, Naval Petroleum Reserve No. 1, Kern County, California, 1995-1996 . . . . . . . . . . 24

10. Total vascular plant cover by lifeform on Hoover's wooly-star reference plots on Naval Petroleum Reserve No. 1, Kern County, California, 1993-1996 . . . . . . 27

11. Floristic survey target species, Naval Petroleum Reserve No. 1, Kern County, California, 1996 
12. Summary of endangered species and cultural resource preactivity surveys conducted during FY96 on the Naval Petroleum Reserves in California, Kern County, California . . . . . . . . . . . . . . . . . . . 35

13. Summary of FY96 cultural resource identification and assessment activities on the Naval Petroleum Reserves in California, Kern County, California

14. Cover and frequency of wildlife and their sign observed on reclaimed sites ten years after reclamation at Naval Petroleum Reserve No. 1, Kern County,

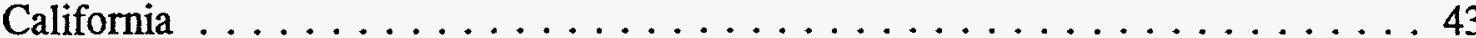




\section{ILLUSTRATIONS}

Figure

Title

Page

1. Location of U. S. Department of Energy's Naval Petroleum Reserves in California, Kern County, California $\ldots \ldots \ldots \ldots \ldots \ldots \ldots \ldots \ldots \ldots \ldots \ldots$

2. Location of San Joaquin kit fox captures, Naval Petroleum Reserves in California, Kern County, California, winter $1995 \ldots \ldots \ldots \ldots \ldots$

3. Spring visitation indices for coyotes on the Naval Petroleum Reserves in California, Kern County, California, 1985-1996 . . . . . . . . . . . . . 9

4. Lagomorphs observed during summer transects on the Naval Petroleum Reserves in California, Kern County, California, 1996

5. Frequency of occurrence of lagomorph and kangaroo rat remains found in San Joaquin kit fox scat collected during winter trapping sessions, Naval Petroleum Reserves in California, Kern County, California, 1983-1995 . . . . . . . . . 16

6. Average Hoover's wooly-star density, frequency of occurrence, and October through March precipitation on permanent reference plots, Naval Petroleum Reserve No. 1, Kern County, California, 1993-1996 . . . . . . . . . . . . . 26

7. Areas surveyed for special status plants at Naval Petroleum Reserves in California, Kern County, California, 1995-1996 . . . . . . . . . . . . . . 29

8. Map depicting Western Naval Petroleum Reserve No. 13 3-D Seismic Survey Program area, Naval Petroleum Reserve No. 1, Kern County, California, 1996 . . 40 


\section{INTRODUCTION}

\subsection{BACKGROUND}

The NPRC are oil fields administered by the U.S. Department of Energy (DOE) in the southern San Joaquin valley of California. Four federally endangered animal species and one federally threatened plant species are known to occur on NPRC: San Joaquin kit fox (Vulpes macrotis mutica), blunt-nosed leopard lizard (Gambelia silus), giant kangaroo rat (Dipodomys ingens), Tipton kangaroo rat (Dipodomys nitratoides), and Hoover's wooly-star (Eriastrum hooveri). All five are protected under the Endangered Species Act (ESA) of 1973 (as amended) (Public Law 93-205), which declares that it is ". . . the policy of Congress that all federal departments and agencies shall seek to conserve endangered species and threatened species and shall utilize their authorities in furtherance of the purposes of the Act." DOE/NPRC is also obliged to determine whether actions taken by their lessees on NPR-2 will have any effects on endangered species or their habitats.

NPR-1 and NPR-2 are located approximately $40 \mathrm{~km}$ southwest of Bakersfield, Kern County, California (Figure 1). NPR-1 encompasses 19,186 ha $(47,409 \mathrm{ac})$ in seven townships and is located just north of NPR-2. DOE/NPRC owns approximately 14,994 ha $(37,049 \mathrm{ac})$ on NPR-1, while Chevron U.S.A. Production Company (CPDN) owns the remaining 4,193 ha $(10,360 \mathrm{ac})$. NPR-2 consists of $12,173 \mathrm{ha}(30,080 \mathrm{ac})$ in five townships. DOE/NPRC administers 4,209 ha $(10,400 \mathrm{ac})$ on NPR-2, while the remainder is privately owned. The city of Taft occupies 518 ha $(1,280 \mathrm{ac})$ in the southern portion of NPR-2.

\subsection{OBJECTIVES}

The primary objective of the EASI Endangered Species and Cultural Resources Program (ESCRP) is to provide NPRC with the scientific expertise necessary for compliance with the ESA, the National Environmental Policy Act (NEPA), and the National Historic Preservation Act (NHPA). The specific objective of this report is to summarize progress, results, and accomplishments of the ESCRP during fiscal year 1996 (FY96). 


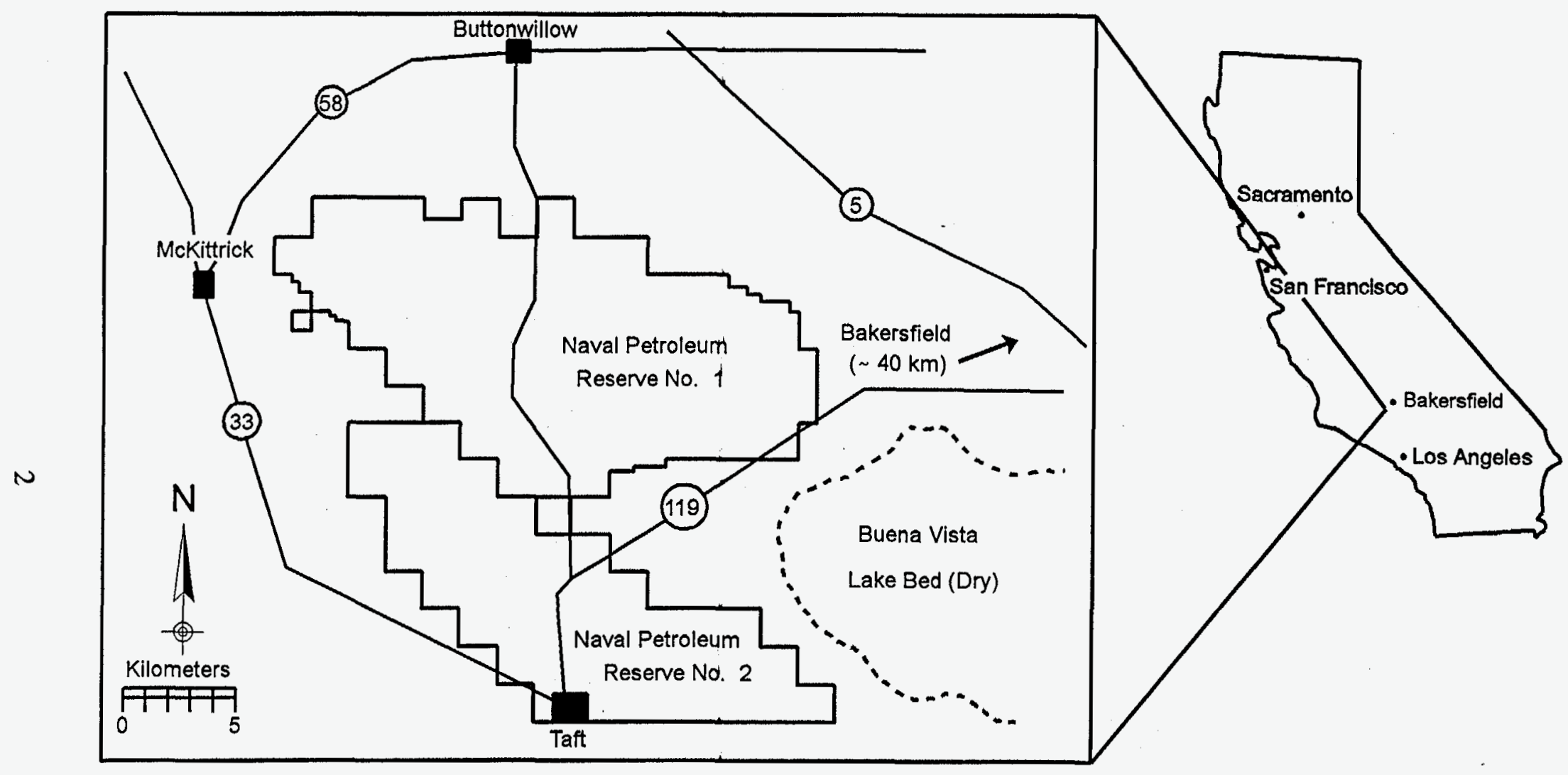

Figure 1. Location of U. S. Department of Energy's Naval Petroleum Reserves in California, Kern County, California. 


\section{ENDANGERED SPECIES MONITORING PROGRAM}

\subsection{MONITOR POPULATIONS OF SAN JOAQUIN KIT FOXES ON NPRC}

\section{INTRODUCTION}

An essential aspect of all endangered species research is some knowledge of the size or density of the population. San Joaquin kit foxes have been trapped annually on NPRC since winter 1981 to provide continuous information on kit fox population trends. The information gathered during this project is also useful in understanding the factors that most strongly affect kit fox populations on NPRC. Knowledge of how these factors influence fox numbers can ultimately be used to help formulate species recovery strategies.

\section{METHODS AND MATERIALS}

Annual kit fox population monitoring was conducted during November and December 1995 over approximately $329-\mathrm{km}^{2}$ on and adjacent to NPRC. NPRC was divided into a number of smaller trap areas, the most important of which are the NPR-1 study area and NPR-2. The NPR-1 study area is a $117-\mathrm{km}^{2}$ area located in the south central portion of NPR-1 and the northern portion of NPR-2. One $38 \times 38 \times 107-\mathrm{cm}$ collapsible wire-mesh live-trap was placed in each quarter section and operated for four consecutive nights. A total of 712 trap-nights of effort was expended on the NPR-1 study area, while 674 trap-nights of effort were expended on NPR-2. Captured kit foxes were individually marked, sexed, weighed, measured, and released at the capture location. The number of foxes captured was tallied for both the NPR-1 study area and NPR-2 and compared with the results of previous trapping sessions.

\section{RESULTS}

During winter 1995, 33 kit foxes were captured 48 times on the NPR-1 study area, while 81 kit foxes were captured 101 times on NPR-2 (Table 1). Compared with 1994, 46\% and 55\% fewer individuals were captured on the NPR-1 study area and NPR-2, respectively.

Foxes were captured at fewer locations in 1995 than 1994 on both NPR-1 and NPR-2. On NPR1 , foxes were primarily captured within or near Buena Vista Valley and along the northwestern boundary (Figure 2). Kit foxes were captured throughout much of NPR-2 in 1995, with most captures occurring within $2 \mathrm{~km}$ of the reserve boundary. 
Table 1. Number of trap-nights, total captures, and individual San Joaquin kit foxes captured during winter live-trapping sessions, Naval Petroleum Reserve No. 1 study area, 1981-1995, and Naval Petroleum Reserve No. 2, 1983-1995, Kern County, California.

\begin{tabular}{|c|c|c|r|r|r|r||}
\hline \multirow{2}{*}{ Year } & \multicolumn{2}{|c|}{ Trap-nights } & \multicolumn{2}{c|}{ Captures } & \multicolumn{2}{c||}{ Individuals } \\
\cline { 2 - 7 } & NPR-1 & NPR-2 & NPR-1 & NPR-2 & NPR-1 & NPR-2 \\
\hline \hline 1981 & 711 & & 209 & & 141 & \\
\hline 1982 & 710 & & 117 & & 87 & \\
\hline 1983 & 712 & 674 & 17 & 88 & 17 & 73 \\
\hline 1984 & 711 & 659 & 51 & 133 & 42 & 113 \\
\hline 1985 & 708 & 673 & 31 & 106 & 26 & 80 \\
\hline 1986 & 712 & 675 & 25 & 124 & 22 & 100 \\
\hline 1987 & 712 & 676 & 27 & 99 & 23 & 76 \\
\hline 1988 & 712 & 676 & 27 & 125 & 23 & 100 \\
\hline 1989 & 712 & 676 & 27 & 77 & 26 & 66 \\
\hline 1990 & 712 & 676 & 28 & 91 & 18 & 64 \\
\hline 1991 & 712 & 671 & 2 & 28 & 2 & 24 \\
\hline 1992 & 712 & 676 & 20 & 63 & 16 & 58 \\
\hline 1993 & 712 & 676 & 50 & 131 & 40 & 108 \\
\hline 1994 & 712 & 676 & 80 & 247 & 61 & 182 \\
\hline 1995 & 712 & 674 & 48 & 101 & 33 & 81 \\
\hline \hline
\end{tabular}

${ }^{2}$ Kit fox monitoring did not begin on NPR-2 until 1983. 
NPR-1

\begin{tabular}{|l|}
\hline Trap Location \\
Fox Capture \\
- Reserve Boundary \\
NPR-1 Study Area
\end{tabular}

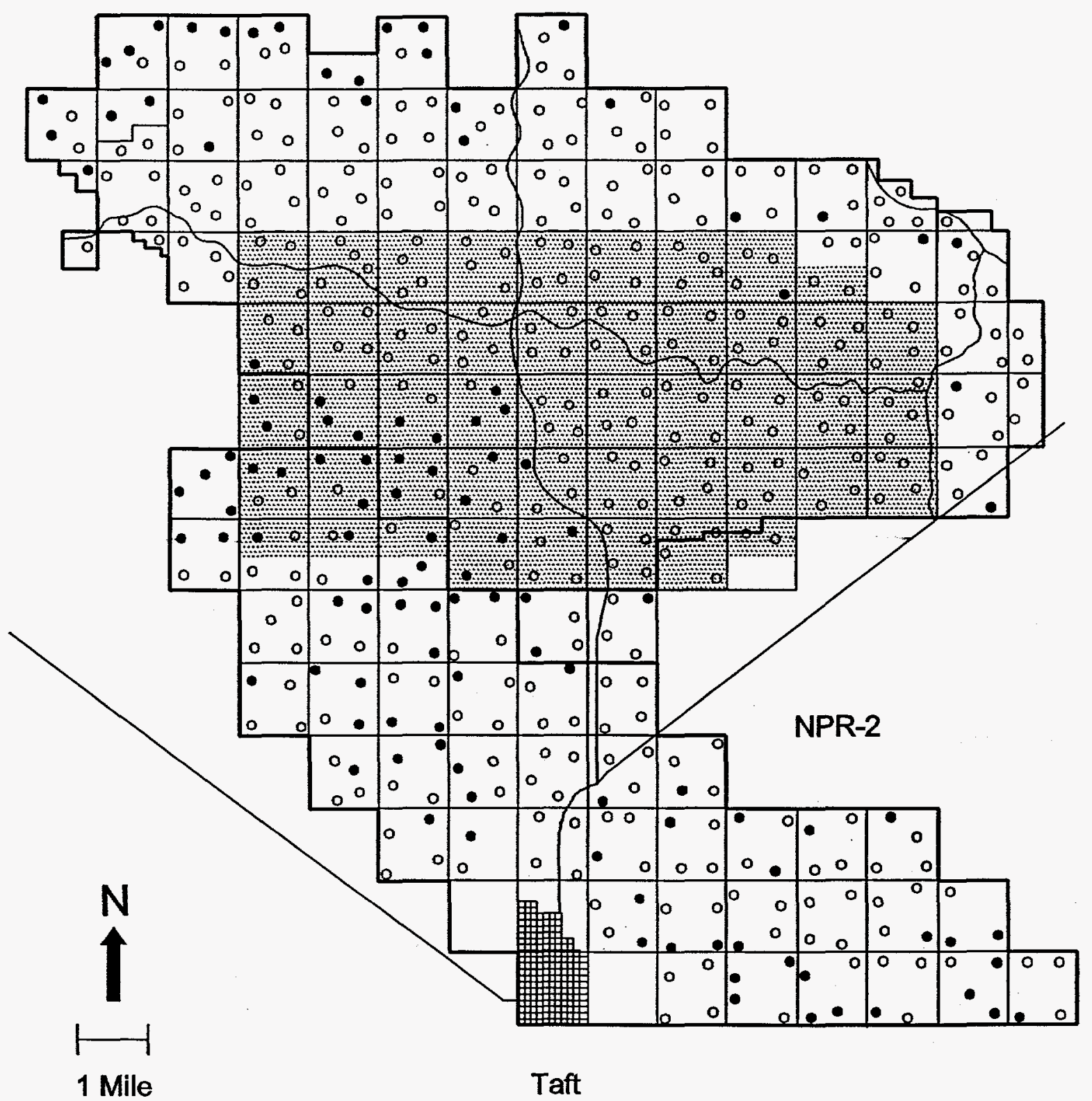

Figure 2. Location of San Joaquin kit fox captures, Naval Petroleum Reserves in California, Kern County, California, winter 1995. 


\section{CONCLUSIONS}

Data collected in 1995 indicate that the kit fox populations on the NPR-1 study area and NPR-2 declined substantially from 1994 levels. Captures were located primarily in flat to moderately hilly terrain and were most numerous in Buena Vista Valley along the NPR-1/NPR-2 boundary. Fox populations likely responded to declines in small mammal prey abundance also observed in 1995. Reductions in prey availability can have profound effects on kit fox breeding success, productivity, pup survival, and adult survival. Some or all of these effects are potentially linked to lower kit fox captures in 1995. Despite the decline, the number of kit foxes in 1995 was intermediate compared to the high and low values on both reserves (Table 1).

\subsection{MONITOR REPRODUCTION AND MORTALITY OF KIT FOXES}

\section{INTRODUCTION}

Kit fox reproduction and mortality were assessed on and adjacent to NPR-1. Using radio telemetry to determine rates of reproduction and mortality among kit foxes can prove useful in assessing changes in population size. The objectives of monitoring reproduction and mortality are to determine: (1) the proportion of adult females that wean pups, (2) the average litter size, and (3) the sources and rates of mortality of juvenile and adult kit foxes on NPRC.

\section{METHODS AND MATERIALS}

Kit foxes were radiocollared and monitored to determine reproductive success, causes of mortality, and mortality rates. During annual trapping sessions conducted in November and December of 1993 - 1995 (see section 2.1), selected adult foxes were fitted with 50-g radiocollars equipped with mortality sensors (MOD-80, Telonics, Mesa, AZ). In May, pups were trapped at their parents' dens and fitted with radiocollars that weighed 25 to 30-g (Model 2A, Telonics). All radiocollared kit foxes were monitored two to three times each week. Kit foxes were recaptured periodically in order to adjust and change radiocollars.

In the spring, kit fox reproduction was assessed by conducting den observations at the dens of all radiocollared kit foxes located. Kit foxes that denned in pipes or deep in the hills were not observed due to the difficulty of receiving radio signals from and locating these foxes. Radiocollared kit foxes were observed at their dens at dusk to count the number of pups present. Adult male kit foxes were monitored at least once, and vixens were monitored twice. In May, traps were set at the dens of kit foxes observed with pups. It was assumed that the female residing at the den where the pups were observed or captured was the mother of the pups. Litter size for each family group was determined as the maximum number of pups trapped or observed at the den. 
Sources and rates of kit fox mortality were assessed by monitoring the fate of radiocollared adult and juvenile kit foxes. Radiocollars were equipped with mortality sensors and would transmit a higher pulse rate when the collar had not moved for at least four hours. When a mortality signal was received, the kit fox was immediately recovered and a necropsy was performed in order to determine the cause of death. Deaths caused by predators were identified by tooth-puncture wounds to the skin and skeleton and by associated hemorrhaging or by the carcass having been buried. Death due to vehicle impact was assumed when kit foxes were recovered in close proximity to roads and evidence of massive trauma was apparent. Kit foxes were classified as having died of unknown causes if the carcass was recovered intact, but no evidence indicating the cause of death could be found. The cause of death was classified as indeterminate if only the radiocollar was recovered or the carcass was too badly scavenged, decomposed, or desiccated to determine the cause of death.

\section{RESULTS AND CONCLUSIONS}

\section{Reproduction}

Of 22 adult kit foxes monitored during FY96 (12 males and 10 females), nine were monitored during February and April for reproductive information. Den observations were conducted at the dens of four radiocollared females and five radiocollared males. None of the males appeared to den with pups. Three pups were observed at the den of one female, and two pups were observed at the den of another female. The other two vixens did not appear to have whelped pups in 1996. In May, traps were set at the pupping dens of the two vixens, and three pups were captured. Two were still too small to be radiocollared so they were eartagged and released. The other pup was radiocollared in late May. A second pup was captured and radiocollared at the den of an adult male which was being trapped to have his collar changed.

The percentage of radiocollared females successfully raising pups was higher in 1996 (50\%, $n=$ 4) than in $1995(25 \%, n=4)$, but sample sizes were so small that any significant change could not be detected. The low reproductive rates for both 1995 and 1996 (in 1994 there was 100\% success in reproduction among radiocollared females) indicate that recruitment of juveniles into the breeding population may be low.

\section{Mortality}

Of 22 adult kit foxes radiocollared prior to or during the 1995 winter trapping session and monitored through September 1996, 15 (68.2\%) were recovered dead and two (9.1\%) were lost because their radiocollars either malfunctioned or expired. Of the $15 \mathrm{kit}$ foxes that died during FY96, eight (53.3\%) were killed by predators, six (40.0\%) died of indeterminate causes, and one (6.7\%) died of an unknown cause. Mortality sources for adult radiocollared kit foxes appeared consistent with those observed for previous years. Radio signals were lost for both juvenile kit foxes soon after collaring in May. It is unknown whether the radios were not transmitting due to 
collar malfunction, if the juveniles dispersed out of range, or if the juveniles died in a pipe or den which impeded signal transmission.

\subsection{MONITOR TRENDS OF CARNIVORE ABUNDANCE}

\section{INTRODUCTION}

Coyote (Canis latrans) predation is the primary source of mortality for kit foxes on NPRC. Coyotes may also compete with kit foxes for food resources. As a result, scent station surveys were established in 1984 to estimate the relative abundance of carnivores, particularly coyotes.

\section{METHODS AND MATERIALS}

Scent station surveys were conducted in late March. Surveys included 23 scent station lines (14 on NPR-1 and nine on NPR-2). Each line contained 10 scent stations placed on alternate sides of secondary roads and spaced at $0.5-\mathrm{km}$ intervals. Each scent station consisted of a circular 0.9$\mathrm{m}$ diameter area cleared of all vegetation and debris. A thin layer of fine dust (approximately 2 $\mathrm{mm}$ ) was sifted over the cleared area and a $2.5-\mathrm{cm}$ plaster-of-Paris disk saturated with a fatty-acid scent attractant was placed in the center. Scent stations were prepared in the afternoon and examined the following morning for the presence of coyote and other carnivore prints. The presence of at least one print at a station constituted a visit. Visitation indices were then calculated as the proportion of operable stations (those not disturbed by wind, rain, or human-related factors) visited multiplied by 1,000 . Wilcoxon signed-rank tests were used to measure differences in visitation indices between years for NPR-1 and NPR-2.

\section{RESULTS AND CONCLUSIONS}

On NPR-1, the visitation index for coyotes was 212 . This suggests that the relative abundance of coyotes has continued to increase following a three-year decline prior to 1993 (Figure 3). This is the highest spring index ever obtained for coyotes on NPR-1 but is not significantly greater than the spring 1995 coyote index, $161(W=45, p=0.32)$. On NPR-2, the visitation index for coyotes was 177, which was higher than the 1995 index of 51. Coyote visits on NPR-2 did not change significantly from 1995 to $1996(W=26, p=0.06)$. 


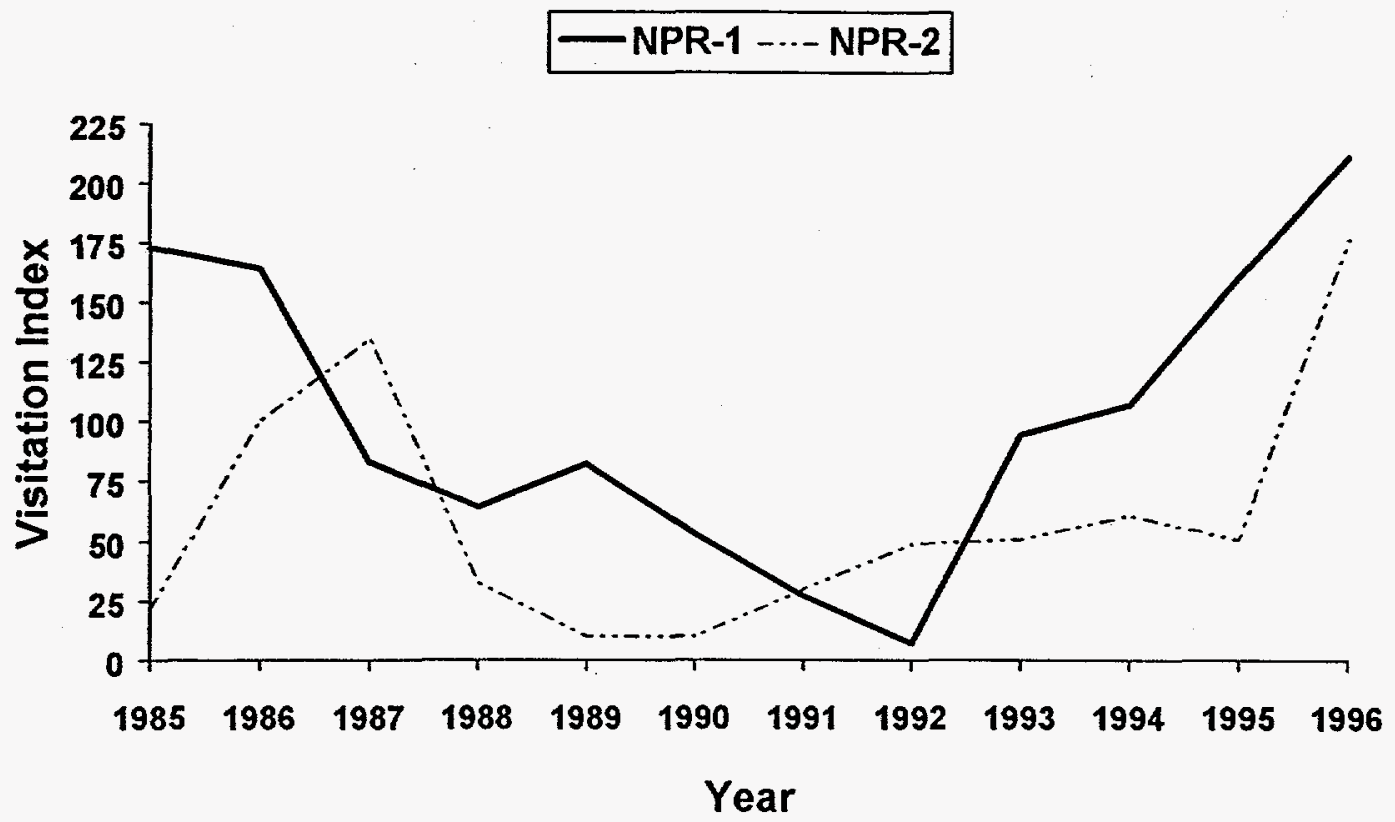

Figure 3. Spring visitation indices for coyotes on the Naval Petroleum Reserves in California, Kern County, California, 1985-1996.

\subsection{MONITOR LAGOMORPH POPULATIONS}

\section{INTRODUCTION}

Lagomorphs, including black-tailed jackrabbits (Lepus californicus) and desert cottontails (Sylvilagus audubonii), are an important prey item for kit foxes. Lagomorph abundance is monitored annually to determine whether fluctuations in lagomorph density directly affect the kit fox population.

\section{METHOD AND MATERIALS}

Lagomorph populations were monitored in June using line-transect surveys conducted in 78 sections on, and adjacent to, NPR-1 and NPR-2. On NPR-1, 24 of 42 transects were located in developed sections, while 18 were located in undeveloped sections. "Developed" sections were those in which more than $15 \%$ of the land was disturbed by oil field development and "undeveloped" sections were those in which $15 \%$ or less of the land was disturbed. On NPR-2, 24 of 36 transects were located in developed sections, while 12 were located in undeveloped sections. 
Transects were $1.6 \mathrm{~km}(1 \mathrm{mi})$ long and consisted of four 400-m legs that formed a square. Observers walked transects between 9:00 am and 4:00 pm and recorded lagomorph species, lagomorph behavior, and the perpendicular distance of observed lagomorphs to the transect line. Program DISTANCE was used to calculate density estimates from recorded perpendicular distances. Estimated densities were compared using $z$-tests.

\section{RESULTS AND CONCLUSIONS}

A total of 34 lagomorphs was observed on NPR-1 in 1996: 27 in developed sections and seven in undeveloped sections (Figure 4). This is $15 \%$ higher than the number of lagomorphs observed in summer 1995 on NPR-1 when 29 were observed. The estimated density of lagomorphs on NPR-1 was $80 / \mathrm{km}^{2}(\mathrm{SE}=20.64)$ and was not significantly more $(z=0.34, p=0.73)$ than the 1995 density estimate of $70 / \mathrm{km}^{2}(\mathrm{SE}=21.86)$. Estimated lagomorph density for developed sections was $73 / \mathrm{km}^{2}(\mathrm{SE}=17.85)$ and was significantly greater $(z=2.43, p=0.02)$ than the estimated density on undeveloped sections, which was $23 / \mathrm{km}^{2}(\mathrm{SE}=9.56)$.

Eighty-four lagomorphs were observed on NPR-2: 61 in developed sections and 23 in undeveloped sections (Figure 4). This represents a $21 \%$ decrease in observations from summer 1995, when 107 lagomorphs were observed. The estimated density of lagomorphs was $238 / \mathrm{km}^{2}$ $(\mathrm{SE}=48.10)$ for all of NPR-2 and was significantly less $(z=2.72, p<0.01)$ than the 1995 density estimate of $505 / \mathrm{km}^{2}(\mathrm{SE}=85.34)$. Estimated lagomorph density for developed sections was $277 / \mathrm{km}^{2}(\mathrm{SE}=54.78)$ and was significantly more $(z=2.03, p=0.04)$ than the estimated density on undeveloped sections, which was $122 / \mathrm{km}^{2}(\mathrm{SE}=53.30)$. The estimated lagomorph density for NPR-1 was $66 \%$ less than that for NPR-2 in 1996. Due to the completion of this study, 1996 was the last year in which lagomorph transects were conducted.

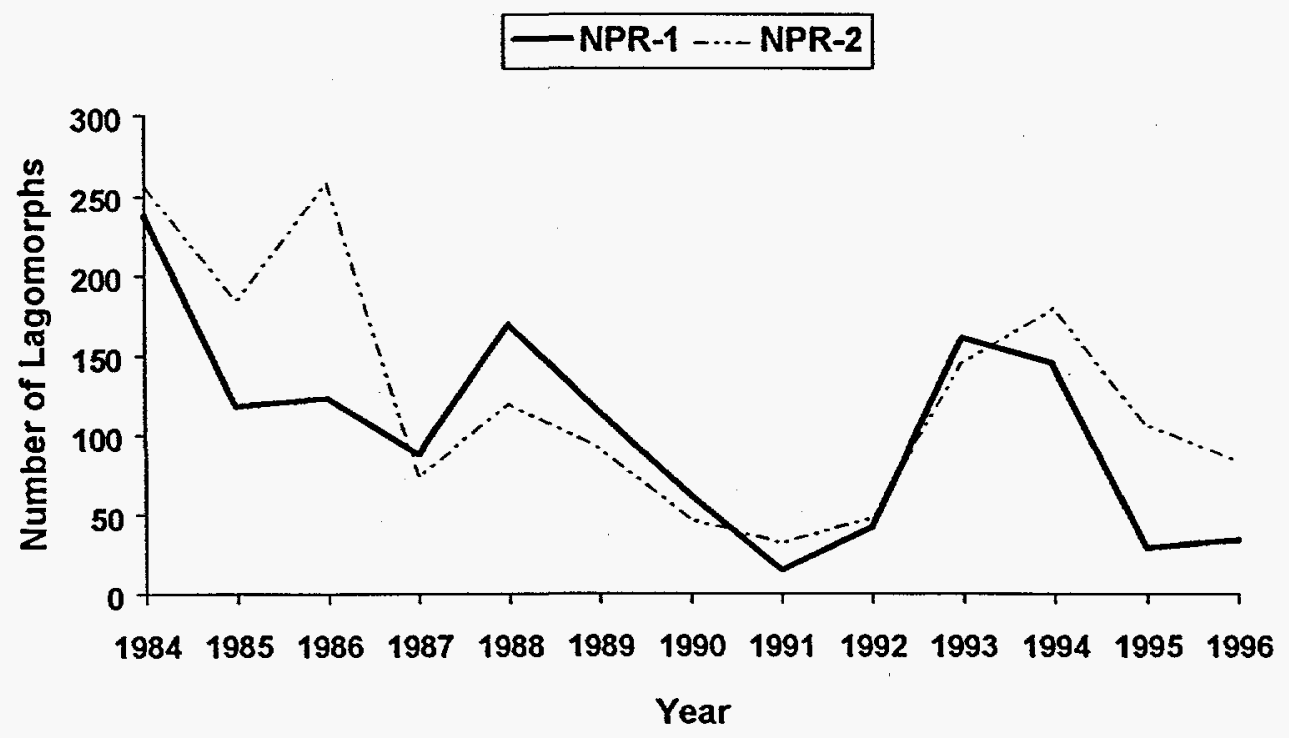

Figure 4. Lagomorphs observed during summer transects on the Naval Petroleum Reserves in California, Kern County, California, 1996. 


\subsection{MONITOR SMALL MAMMAL POPULATIONS}

\section{INTRODUCTION}

A program was initiated in FY93 to monitor abundance and habitat relationships of small mammals on NPR-1. Information obtained from this effort may help explain observed kit fox population trends because small mammals, particularly kangaroo rats, are important prey of kit foxes. Also, understanding small mammal habitat relationships may help explain kit fox distribution patterns on NPR-1. Finally, this monitoring program will provide an annual assessment of the abundance and habitat preferences of several species that are considered rare but are not listed. Therefore, specific objectives of small mammal monitoring are to: (1) assess the annual abundance and species composition of small mammals on NPR-1, and (2) determine the effects of physiographic and vegetation characteristics on small mammal abundance and species composition.

\section{METHODS AND MATERIALS}

Small mammal abundance and habitat relationships were assessed by live-trapping at 20 permanent monitoring sites. Five sites were established in each of four physiographic regions (South-Flat, South-Hilly, North-Flat, and North-Hilly) based on slope orientation (north or south side of Elk Hills ridge) and terrain (flat terrain $=0-5^{\circ}$ slope, hilly terrain $=>5^{\circ}$ slope). At each site, 25 trap stations were established at 7.5-m intervals along an east-west transect. Two Sherman livetraps were placed at each station for a total of 50 traps per site. Traps were prebaited for three days prior to trapping. During trapping, traps were set in late afternoon and then checked the next morning. Captured small mammals were identified to species, marked ventrally with a non-toxic marking pen, sexed, aged, weighed, and released at the capture site.

To examine the relationship between small mammals and vegetation characteristics, vegetation sampling transects were established at each monitoring site. These transects were $200 \mathrm{~m}$ long, and were placed $10 \mathrm{~m}$ south of and parallel to each small mammal trapping transect. Percent cover of grasses, forbs, and all vegetation was estimated by using an ocular point projection device. Five points were sampled at 5-m intervals along the transect for a total of 200 points per site. To estimate annual primary production on sites, $0.25-\mathrm{m}^{2}$ quadrats were established at $20-\mathrm{m}$ intervals along sampling transects. On each quadrat, forbs and grasses were clipped and placed in separate bags. All samples were dried and weighed.

\section{RESULTS}

Small mammal trapping was conducted for five consecutive nights from September 16-20, 1996. During this period, 238 individuals of seven species were trapped 623 times in 4,997 trap-nights (Table 2). Heermann's kangaroo rat (Dipodomys heermanni) was the most frequently captured species. Mean capture rate (mean number of individuals captured per 100 trap-nights) for all species combined varied among regions $(F=4.78 ; 3,16 \mathrm{df} ; P=0.01)$ and was highest on South- 
Hilly sites. On individual sites, capture rates were not correlated with either percent total cover or total production.

Mean percent cover did not vary significantly among regions for grass, forbs, or total plant cover (Table 3). Similarly, mean production also did not vary among regions for grass, forbs, or total production (Table 3 ).

Mean capture rate for all small mammals was significantly lower in 1996 compared to all previous monitoring years $(F=23.0 ; 3,76 \mathrm{df} ; p<0.01)$ (Table 4$)$. Mean vegetative cover differed significantly among years $(F=107.4 ; 3,76 \mathrm{df} ; p<0.01)$ with 1996 cover estimates being the second highest recorded. Mean vegetative production also differed significantly among years $(F$ $=76.0 ; 2,57 \mathrm{df} ; p<0.01$ ); production in 1996 was lower compared to 1995 but higher compared to 1994 (Table 4).

Community composition varied among physiographic regions in 1996 (Table 2). Heermann's kangaroo rat was the most abundant species on hilly sites while San Joaquin pocket mouse (Perognathus inornatus) was the most abundant species on flat sites. As in 1995, relatively few short-nosed kangaroo rats $(D$. nitratoides) or San Joaquin antelope squirrels (Ammospermophilus nelsoni) were captured (Table 4). San Joaquin pocket mice, which were abundant in all regions in 1995, were much less abundant in 1996 and were primarily captured on North-Flat sites. Five other species were infrequently captured. Deer mice (Peromyscus maniculatus) were captured only in hilly regions while grasshopper mice (Onychomys torridus) were captured in all regions. No giant kangaroo rats $(D$. ingens) were captured in 1996 . Finally, one western harvest mouse (Reithrodontomys megalotis) was captured. Mean Shannon diversity indices were similar among regions (Table 3). Diversity on individual sites was not correlated to either total cover or total production.

Kangaroo rats are the small mammals most frequently preyed upon by kit foxes. Therefore, kangaroo rat abundance may influence kit fox distribution and abundance. Mean capture rate for all kangaroo rat species combined varied significantly among regions $(F=9.03 ; 3,16 \mathrm{df} ; p<$ 0.01 ). As in 1995 , kangaroo rat capture rates were significantly higher in hilly regions. Mean ( \pm SE) capture rates were $5.6 \pm 1.5$ and $6.2 \pm 1.3$ in the North-Hilly and South-Hilly regions, respectively, and $0.3 \pm 0.2$ and $0.8 \pm 0.3$ in the North-Flat and South-Flat regions, respectively. Kangaroo rat capture rates on individual monitoring sites were not significantly correlated with total production, but approached a significant negative correlation with total cover $(r=0.38 ; F$ $=3.13 ; p=0.09$ ). Kangaroo rat captures consisted primarily of Heermann's kangaroo rats. As in 1995, relatively few short-nosed kangaroo rats were captured. Mean ( \pm SE) kangaroo rat capture rate was significantly lower in $1995(5.5 \pm 1.4)$ and $1996(3.2 \pm 0.8)$ compared to 1993 $(11.3 \pm 1.0)$ or $1994(14.1 \pm 0.8)(F=24.68 ; 3,76 \mathrm{df} ; p<0.01)$. 
Table 2. Small mammal captures and diversity indices within four physiographic regions on Naval Petroleum Reserve No. 1, Kern County, California, 1996.

\begin{tabular}{|c|c|c|c|c|c|c|c|c|c|c|c|}
\hline \multirow[t]{2}{*}{ Treatment } & \multicolumn{8}{|c|}{ Individuals $^{\mathbf{a}}$} & \multirow[b]{2}{*}{$\begin{array}{l}\text { Trap- } \\
\text { nights }\end{array}$} & \multirow{2}{*}{$\begin{array}{c}\text { Mean }^{\mathrm{b}} \\
\text { Capture } \\
\text { Rate (SE) }\end{array}$} & \multirow{2}{*}{$\begin{array}{c}\text { Mean }^{c} \\
\text { Shannon } \\
\text { Diversity } \\
\text { Index (SE) }\end{array}$} \\
\hline & SNKR & HKR & GKR & SJPM & DM & SGM & SJAS & Total & & & \\
\hline South-Flat & 8 & 2 & 0 & 4 & 0 & 4 & 3 & 21 & 1,250 & $1.7 \mathrm{~B}^{\mathrm{d}}(0.4)$ & $\begin{array}{c}0.36 \mathrm{~A} \\
(1.00)\end{array}$ \\
\hline South-Hilly & 9 & 68 & 0 & 2 & 5 & 8 & 3 & 95 & 1,246 & $7.6 \mathrm{~A}(1.6)$ & $0.33 \mathrm{~A}(0.07)$ \\
\hline North-Flat & 1 & 3 & 0 & 27 & 0 & 1 & 0 & 32 & 1,249 & $\begin{array}{c}2.6 \mathrm{AB} \\
(1.2)\end{array}$ & $0.12 \mathrm{~A}(0.06)$ \\
\hline North-Hilly & 0 & 70 & 0 & 4 & 10 & 4 & 1 & $90^{\circ}$ & 1,244 & $\begin{array}{c}7.2 \mathrm{AB} \\
(2.0)\end{array}$ & $0.23 \mathrm{~A}(0.07)$ \\
\hline
\end{tabular}

a

SNKR $=$ Short-nosed kangaroo rat

HKR = Heermann's kangaroo rat

GKR $=$ Giant kangaroo rat

SJPM $=$ San Joaquin pocket mouse

$\mathrm{DM}=$ Deer mouse

SGM $=$ Southern grasshopper mouse

SJAS $=$ San Joaquin antelope squirrel

${ }^{b}$ Mean number of individuals captured per 100 trapnights.

${ }^{\mathrm{c}}$ Shannon Diversity Index $=\frac{n \log n-\Sigma f_{i} \log f_{i}}{n}$, where $\mathrm{f}_{\mathrm{i}}$ is number of individuals of the ith species.

${ }^{\mathrm{d}}$ Means with the same letter within a column were not significantly different.

${ }^{\mathrm{e}}$ North-Hilly total includes one western harvest mouse. 
Table 3. Mean percent cover and mean herbaceous production estimated in four physiographic regions on Naval Petroleum Reserve No. 1, Kern County, California, 1996.

\begin{tabular}{||c|c|c|c|c|c|c||}
\hline \multirow{2}{*}{ Treatment } & \multicolumn{3}{|c|}{ Mean Percent Cover (SE) } & \multicolumn{3}{c||}{ Mean Production (kg/ha) (SE) } \\
\cline { 2 - 7 } & Total & Grass & Forb & Total & Grass & Forb \\
\hline \hline \multirow{2}{*}{ South-Flat } & 71.9 & 66.3 & 4.8 & 1596.8 & 1514.0 & 82.8 \\
& $(3.4)$ & $(3.1)$ & $(2.4)$ & $(356.9)$ & $(385.7)$ & $(33.3)$ \\
\hline \multirow{2}{*}{ South-Hilly } & 76.2 & 67.9 & 1.2 & 1580.1 & 1566.2 & 13.9 \\
& $(3.5)$ & $(3.3)$ & $(1.1)$ & $(197.5)$ & $(196.3)$ & $(7.3)$ \\
\hline \multirow{2}{*}{ North-Flat } & 81.5 & 74.6 & 3.0 & 1164.2 & 1115.4 & 48.9 \\
& $(2.5)$ & $(2.6)$ & $(2.9)$ & $(163.7)$ & $(132.5)$ & $(34.1)$ \\
\hline \multirow{2}{*}{ North-Hilly } & 74.2 & 63.2 & 6.3 & 1143.8 & 1036.9 & 106.9 \\
& $(4.9)$ & $(7.8)$ & $(4.5)$ & $(173.0)$ & $(203.5)$ & $(82.8)$ \\
\hline
\end{tabular}

Table 4. Annual comparison of small mammal capture rates, vegetative cover and production, and small mammal diversity indices on Naval Petroleum Reserve No. 1, Kern County, California, 1993-1996.

\begin{tabular}{|c|c|c|c|c|c|c|c|c|c|c|c|c|c||}
\hline \hline \multirow{2}{*}{ Year } & \multicolumn{9}{|c|}{ Individuals $^{2}$} & $\begin{array}{c}\text { Mean } \\
( \pm \text { SE }) \\
\text { Capture } \\
\text { Rate }\end{array}$ & $\begin{array}{c}\text { Mean } \\
( \pm \text { SE }) \\
\text { Cover } \\
(\%)\end{array}$ & $\begin{array}{c}\text { Mean } \\
( \pm \text { SE }) \\
\text { Prod. } \\
(\mathrm{kg} / \mathrm{ha})\end{array}$ & $\begin{array}{c}\text { Mean } \\
( \pm \text { SE }) \\
\text { Diversity } \\
\text { Index }\end{array}$ \\
\hline \hline 1993 & 190 & 375 & 1 & 7 & 51 & 19 & 75 & - & 718 & $\begin{array}{c}14.4 \mathrm{AB}^{\mathrm{c}} \\
(1.0)\end{array}$ & $\begin{array}{c}70.5 \mathrm{~B} \\
(2.9)\end{array}$ & - & $\begin{array}{c}0.38 \mathrm{~A} \\
(0.02)\end{array}$ \\
\hline 1994 & 278 & 418 & 5 & 10 & 12 & 16 & 41 & - & 780 & $\begin{array}{c}15.6 \mathrm{~A} \\
(0.9)\end{array}$ & $\begin{array}{c}27.2 \mathrm{C} \\
(2.3)\end{array}$ & $\begin{array}{c}269 \mathrm{C} \\
(29.2)\end{array}$ & $\begin{array}{c}0.30 \mathrm{~A} \\
(0.03)\end{array}$ \\
\hline 1995 & 21 & 255 & 1 & 245 & 6 & 18 & 15 & 3 & 564 & $\begin{array}{c}11.4 \mathrm{~B} \\
(1.2)\end{array}$ & $\begin{array}{c}85.8 \mathrm{~A} \\
(1.5)\end{array}$ & $\begin{array}{c}1733 \mathrm{~A} \\
(88.8)\end{array}$ & $\begin{array}{c}0.27 \mathrm{~A} \\
(0.04)\end{array}$ \\
\hline 1996 & 18 & 143 & 0 & 37 & 15 & 17 & 7 & 1 & 238 & $\begin{array}{c}4.8 \mathrm{C} \\
(0.9)\end{array}$ & $\begin{array}{c}76.0 \mathrm{~B} \\
(1.9)\end{array}$ & $\begin{array}{c}1371 \mathrm{~B} \\
(119.3)\end{array}$ & $\begin{array}{c}0.26 \mathrm{~A} \\
(0.04)\end{array}$ \\
\hline
\end{tabular}

a

SNKR $=$ Short-nosed kangaroo rat

HKR $=$ Heermann's kangaroo rat

GKR = Giant kangaroo rat

SJPM $=$ San Joaquin pocket mouse
$\mathrm{DM}=$ Deer mouse

SGM $=$ Southern grasshopper mouse

SJAS $=$ San Joaquin antelope squirrel

Other $=$ House mouse and western harvest mouse

${ }^{b}$ Mean number of individuals captured per 100 trapnights.

${ }^{\mathrm{c}}$ Means with the same letter within a column were not significantly different. 


\section{CONCLUSIONS}

Small mammal abundance continued to be low in 1996 despite relatively high vegetative production and apparently favorable environmental conditions. Small mammal populations do not appear to have recovered from the significant decline in abundance observed after heavy precipitation in 1995. Indeed, capture rates for Heermann's kangaroo rats, San Joaquin pocket mice, and San Joaquin antelope squirrels declined further. The causal mechanism resulting in the decline in small mammal abundance in 1995 and continued low abundance in 1996 has not been identified. Interestingly, the decline appears to have been more pronounced in flat terrain, which tends to occur at lower elevations. Small mammal abundance also declined in hilly terrain, but the reduction was not as pronounced. This pattern further indicates that oilfield activities were not responsible for the decline because relatively little oilfield activity occurs in areas with flat terrain.

Small mammal abundance patterns on NPRC do not appear to explain observed patterns of kit fox abundance. Kit foxes are most abundant in the areas of NPRC with relatively flat terrain. The decline in small mammal abundance is likely at least partly responsible for the observed decline in kit fox abundance (see Section 2.1). Also, concomitant with reduced small mammal abundance, the occurrence of small mammals in kit fox scats declined while the occurrence of lagomorphs increased (see Section 2.6).

\subsection{DETERMINE DIET OF KIT FOXES}

\section{INTRODUCTION}

Kit fox food habits were assessed on NPRC by collecting scats from kit foxes trapped during winter intensive trapping and throughout FY96. Frequency of occurrence of prey items in kit fox scat can indicate changes in prey availability, differences in prey densities throughout NPRC, and kit fox food preferences.

\section{METHODS AND MATERIALS}

Kit fox diet was determined by analyzing scats collected from live-trapped foxes. Fresh scats were dried and sent to a diagnostic laboratory for analysis (Global Ecosystem Managers, Baton Rouge, LA). Differences between NPR-1 and NPR-2 in the frequency of occurrence of prey items were compared using a Chi-square test with a Cochran correction for continuity. 


\section{RESULTS AND CONCLUSIONS}

Of 154 scats collected during FY96 winter intensive trapping, rodents, mostly consisting of kangaroo rats, occurred in $45.5 \%$ of the scats, and continued to be the primary prey item consumed by kit foxes on NPRC (Table 5). Lagomorphs, including jackrabbits and cottontail rabbits, had the second highest frequency of occurrence with $31.2 \%$. Insects were found in $17.5 \%$ of all scats. The frequency of occurrence of kangaroo rats and lagomorphs in scats differed significantly between NPR-1 and NPR-2 (lagomorphs: $\chi^{2}=19.4$, $\mathrm{df}=1, \mathrm{n}=157$, kangaroo rats: $\chi^{2}=21.5, \mathrm{df}=1, \mathrm{n}=157$ ). As was noted in previous years, kit foxes exhibited a greater use of lagomorph prey on NPR-2 than on NPR-1. This discrepancy has been attributed to greater lagomorph abundance on NPR-2 (Section 2.4). Kit foxes exhibited a shift in primary prey, from lagomorphs to kangaroo rats, over the years (Figure 5). In recent years kangaroo rat populations have decreased dramatically (Section 2.5), possibly explaining the trend in increased lagomorph consumption.

\section{$\square$ Lagomorph $\square$ Kangaroo Rat}

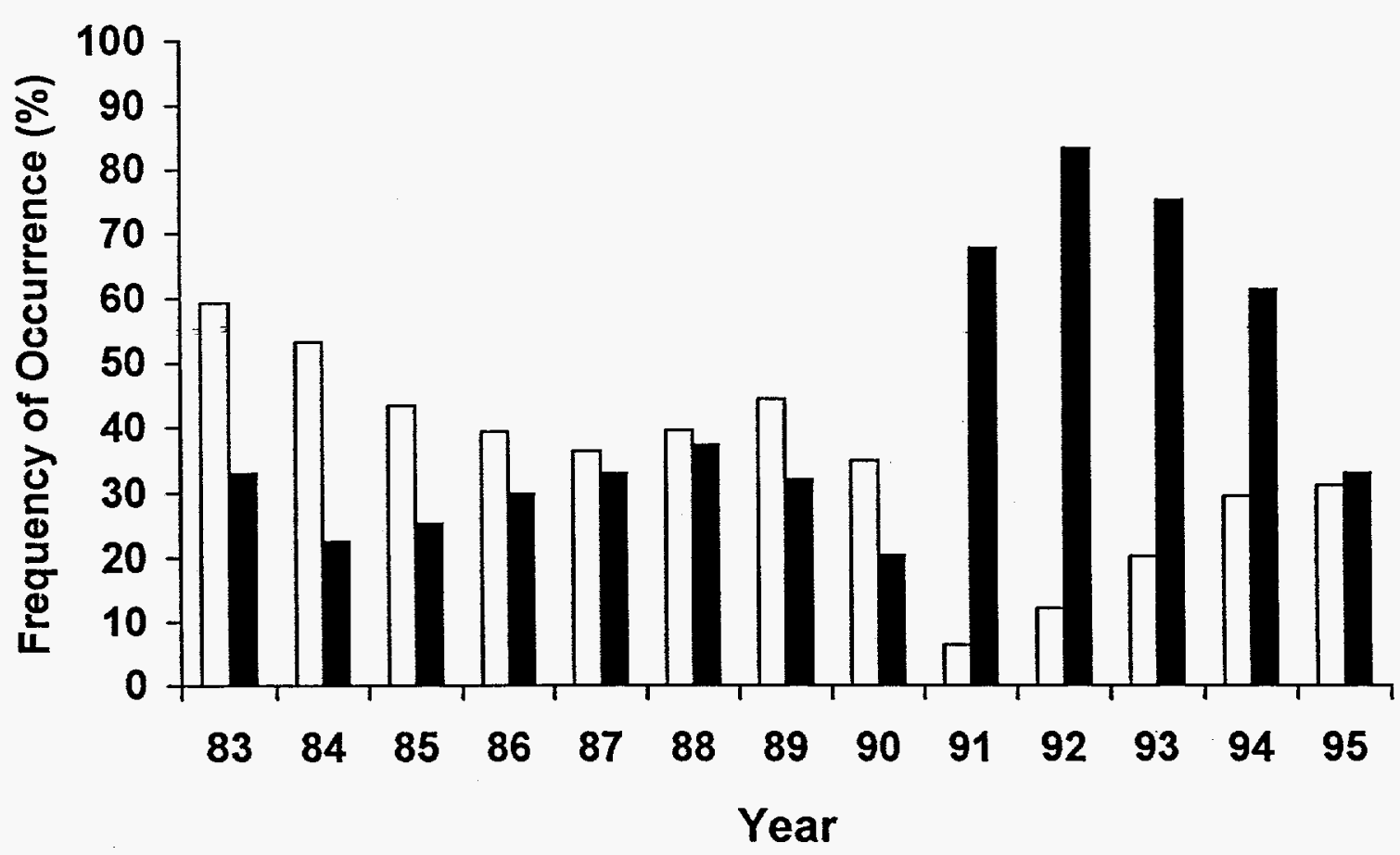

Figure 5. Frequency of occurrence of lagomorph and kangaroo rat remains found in San Joaquin kit fox scat collected during winter trapping sessions, Naval Petroleum Reserves in California, Kern County, California, 1983-1995. 
Table 5. Frequency of occurrence (\%) of items found in San Joaquin kit fox scat, Naval Petroleum Reserves in California, Kern County, California, 1996.

\begin{tabular}{|c|c|c|c|c|c|c|}
\hline \multirow{2}{*}{ Food Item } & \multicolumn{2}{|c|}{ NPR-1 } & \multicolumn{2}{|c|}{ NPR-2 } & \multicolumn{2}{|c|}{ TOTAL } \\
\hline & $\mathbf{n}$ & $\%$ & $\mathbf{n}$ & $\%$ & $\mathbf{n}$ & $\%$ \\
\hline Lagomorph & 7 & 10.9 & 41 & 44.1 & 48 & 31.2 \\
\hline Rodent & 40 & 62.5 & 30 & 32.3 & 70 & 45.5 \\
\hline Kangaroo rat & 29 & 45.3 & 22 & 23.7 & 51 & 33.1 \\
\hline $\begin{array}{l}\text { San Joaquin antelope } \\
\text { squirrel }\end{array}$ & 4 & 6.3 & 3 & 3.2 & 7 & 4.6 \\
\hline $\begin{array}{l}\text { San Joaquin pocket } \\
\text { mouse }\end{array}$ & 2 & 3.1 & 1 & 1.1 & 3 & 2.0 \\
\hline Cricetid & 2 & 3.1 & 2 & 2.2 & 4 & 2.6 \\
\hline Botta pocket gopher & 3 & 4.7 & 2 & 2.2 & 5 & 3.3 \\
\hline Bird & 3 & 4.7 & 1 & 1.1 & 4 & 2.6 \\
\hline Reptile & 4 & 6.3 & 2 & 2.2 & 5 & 3.3 \\
\hline Snake & 4 & 6.3 & 2 & 2.2 & 5 & 3.3 \\
\hline Insect & 5 & 7.8 & 22 & 23.7 & 27 & 17.5 \\
\hline Cricket/Grasshopper & 3 & 4.7 & 6 & 6.5 & 9 & 5.8 \\
\hline Beetle & 2 & 3.1 & 16 & 17.2 & 18 & 11.7 \\
\hline Non-food items & 5 & 7.8 & 11 & 11.8 & 16 & 10.4 \\
\hline Wool & 1 & 1.6 & 4 & 4.3 & 5 & 3.3 \\
\hline Fox hair & 4 & 6.3 & 3 & 3.2 & 7 & 4.6 \\
\hline Grass & 0 & 0 & 4 & 4.3 & 4 & 2.6 \\
\hline Empty & 10 & 15.6 & 7 & 7.5 & 16 & 10.4 \\
\hline Other & 6 & 9.4 & 10 & 10.8 & 14 & 9.1 \\
\hline Total \# of scats collected & & & & & & \\
\hline
\end{tabular}

a Three scats were collected in an area included in analyses for both NPR-1 and NPR-2. 


\subsection{GIANT KANGAROO RAT POPULATION MONITORING}

\section{INTRODUCTION}

In 1994, a program was initiated to monitor giant kangaroo rats on NPR-1. Objectives of the program were to (1) monitor annual population trends, and (2) collect demographic information that would contribute to regional conservation efforts.

\section{METHODS AND MATERIALS}

Monitoring was conducted by live-trapping on a grid plot and assessing the dynamics of a sample of giant kangaroo rat colonies. A 12 x 12 trapping grid was established in summer 1994 on a site occupied by giant kangaroo rats. Trap stations were placed at $15-\mathrm{m}$ intervals and one Sherman live-trap was placed at each station. Two trapping sessions were conducted, one in March and one in August. Traps were prebaited for three nights, and then opened in the afternoon, baited, and checked for six consecutive mornings. Captured small mammals were identified to species, marked ventrally with a non-toxic pen, sexed, aged, weighed, and released at the capture site. All kangaroo rats were also eartagged.

Vegetation characteristics including vegetative production, shrub density, and cover of grass, forb, and shrub species were measured on the monitoring plot in 1996. Results were compared between years using two sample $t$-tests. This was done to determine whether annual fluctuations in environmental conditions influence giant kangaroo rat population trends.

Beginning in 1993, the dynamics of several giant kangaroo rat colonies were assessed on an annual basis. Colony size was based on the number of active precincts (burrow systems) comprising the colony. Parallel transects were walked through colonies and active precincts were marked with pin flags. Criteria used to identify active precincts included presence of clipped vegetation, haystacking of clipped vegetation, large diameter burrow entrances, vertical burrow entrances, pit caching, and large-sized scats ( $27-\mathrm{mm})$.

\section{RESULTS}

\section{Live-Trapping}

Live-trapping results on the 2B grid plot resulted with one giant kangaroo rat capture in the spring session and zero giant kangaroo rat captures in the fall session (Table 6). Other species captured included the short-nosed kangaroo rat, San Joaquin antelope squirrel, San Joaquin pocket mouse, and the Southern grasshopper mouse. 
Table 6. Small mammal captures on the giant kangaroo rat plot, Naval Petroleum Reserves in California, Kern County, California, 1994-1996.

\begin{tabular}{||l|c|c|c|c|c||}
\hline \multirow{2}{*}{ Species } & \multicolumn{5}{c|}{ Trapping Session } \\
\cline { 2 - 7 } & $\begin{array}{c}\text { Fall } \\
\mathbf{1 9 9 4}\end{array}$ & $\begin{array}{c}\text { Spring } \\
\mathbf{1 9 9 5}\end{array}$ & $\begin{array}{c}\text { Fall } \\
\mathbf{1 9 9 5}\end{array}$ & $\begin{array}{c}\text { Spring } \\
\mathbf{1 9 9 6}\end{array}$ & $\begin{array}{c}\text { Fall } \\
\mathbf{1 9 9 6}\end{array}$ \\
\hline \hline Giant kangaroo rat & 11 & 5 & 1 & 1 & 0 \\
\hline Southern grasshopper mouse & 3 & 0 & 1 & 2 & 3 \\
\hline Short-nosed kangaroo rat & 107 & 13 & 3 & 9 & 2 \\
\hline San Joaquin pocket mouse & 2 & 4 & 33 & 68 & 64 \\
\hline San Joaquin antelope squirrel & 10 & 1 & 6 & 5 & 1 \\
\hline Heerman's kangaroo rat & 9 & 0 & 0 & 0 & 0 \\
\hline
\end{tabular}

Comparisons of data from 1994 to fall of 1995 indicate a continued decline in numbers for giant kangaroo rats and most small mammal species captured on the monitoring plot (Table 6). San Joaquin pocket mouse numbers remained high.

Mean percent cover on the monitoring plot did not differ between 1995 and 1996, although vegetative composition varied, with grass being significantly more abundant in $1996(t=6.00$; $p<0.01)$ and forbs being significantly more abundant in $1995(t=7.50 ; p<0.01)$ (Table 7). In addition, mean herbaceous production increased in 1996, although not significantly $(t=0.90$; $p=0.40)$.

\section{Colony Assessments}

Fourteen giant kangaroo rat colony assessments were completed in August and September 1996 (Table 8). All but two of these colonies were actively being used. Of the 13 colonies monitored in 1995, all were assessed in 1996, with the exception of those in sections 1B, 20S, 21S, and 26S, which had no active precincts in 1995. Additional colonies were assessed during 1996 in 10R, $11 \mathrm{Z}, 13 \mathrm{Z}$, and $14 \mathrm{Z}$ and were all found to be active. From 1995 to 1996, five of the colonies decreased in size, two increased, and two remained the same. In 1996, the number of active giant kangaroo rat precincts in each colony ranged from one to 113, while in 1995, it ranged from three to 241 . 
Table 7. Mean percent cover and mean herbaceous production estimated on the giant kangaroo rat monitoring plot, Naval Petroleum Reserve No. 1, Kern County, California, 1995-1996.

\begin{tabular}{||c|c|c|c|c|c|c||}
\hline \multirow{2}{*}{ Year } & \multicolumn{3}{|c|}{ Mean Percent Cover (SE) } & \multicolumn{3}{c|}{ Mean Production (kg/ha) (SE) } \\
\cline { 2 - 7 } & Total & Grass & Forb & Total & Grass & Forb \\
\hline \hline \multirow{2}{*}{1995} & 85.4 & 54.4 & 31.0 & 1218.5 & 709.1 & 509.4 \\
& $(2.6)$ & $(2.6)$ & $(3.5)$ & $(150.8)$ & $(121.1)$ & $(111.0)$ \\
\hline \multirow{2}{*}{1996} & 85.0 & 81.4 & 3.6 & 1539.6 & 1409.5 & 130.1 \\
& $(3.8)$ & $(3.7)$ & $(1.0)$ & $(325.3)$ & $(317.9)$ & $(35.6)$ \\
\hline
\end{tabular}


Table 8. Number of active giant kangaroo rat precincts in colonies monitored from Naval Petroleum Reserves in California, Kern County, California, 1993-1996.

\begin{tabular}{|c|c|c|c|c|}
\hline Section & 1993 & 1994 & 1995 & 1996 \\
\hline 1B & 3 & 3 & 0 & - \\
\hline $2 \mathrm{~B}$ & - & - & 6 & 6 \\
\hline $9 \mathrm{~B}$ & - & 46 & 4 & 28 \\
\hline $11 \mathrm{~B}$ & 19 & 16 & 11 & 3 \\
\hline $13 \mathrm{~B}$ & 5 & 43 & 15 & 26 \\
\hline $15 \mathrm{~B} / 21 \mathrm{~B}-22 \mathrm{~B}$ & - & $36 / 186$ & $44 / 178$ & $24 / 22$ \\
\hline $17 \mathrm{~B}$ & - & 10 & 0 & 0 \\
\hline $35 \mathrm{~B}$ & - & 93 & 3 & 0 \\
\hline $11 \mathrm{G}$ & 1 & 95 & 241 & 113 \\
\hline $18 \mathrm{G}$ & 18 & 68 & 12 & 1 \\
\hline $10 \mathrm{R}$ & - & - & - & 19 \\
\hline $20 \mathrm{~S}$ & - & 4 & 0 & - \\
\hline $21 \mathrm{~S}$ & - & 0 & $\theta$ & - \\
\hline $26 S$ & - & 0 & 0 & - \\
\hline $\mathrm{NE} / \mathrm{SE} 11 \mathrm{Z}$ & - & - & - & 85 \\
\hline SE/SE $11 Z$ & - & - & - & 78 \\
\hline $13 Z$ & - & - & - & 42 \\
\hline $14 Z$ & - & - & - & 13 \\
\hline
\end{tabular}

\section{CONCLUSIONS}

Most giant kangaroo rat colonies decreased in size in 1996. Similarly, trapping results also indicated a continued decline in population numbers. The increase in mean percent grass cover and herbaceous production in 1996 suggest that environmental conditions were favorable. Thus, the reasons for continued low giant kangaroo rat abundance are unknown. 


\subsection{BLUNT-NOSED LEOPARD LIZARD POPULATION MONITORING}

\section{INTRODUCTION}

Studies have been conducted on and adjacent to NPR-1 to define the distribution, abundance, and habitat use of the blunt-nosed leopard lizard. Suitable blunt-nosed leopard lizard habitat is found on NPR-1 in flat areas with sparse vegetation, and in gentle to moderate sloping areas with large washes. Blunt-nosed leopard lizards were found to occur in low numbers and generally near the borders of the reserve. The objectives of this monitoring task are to: 1) assess the annual abundance of blunt-nosed leopard lizards, 2) determine whether blunt-nosed leopard lizard population trends differ between a developed area and an undeveloped area, 3 ) assess the effects of habitat features (e.g., roads, pipelines, washes) on blunt-nosed leopard lizard space use patterns, 4) collect demographic data to contribute to on-site and range-wide conservation and recovery efforts, and 5) determine whether annual variation in vegetation characteristics influences blunt-nosed leopard lizard abundance.

\section{METHODS AND MATERIALS}

Blunt-nosed leopard lizards are monitored using transect surveys conducted on two 16-ha study plots established on NPR-1. One plot is located in a section that is less than 5\% developed (4B), and the other is located in a section that is more than $15 \%$ developed $(18 \mathrm{G})$. Both plots have similar terrain and habitat features. Each 16-ha plot is composed of 16 to 20 parallel transects spaced $20 \mathrm{~m}$ apart. Ten surveys are conducted on each plot in the spring to assess the abundance of adults, and again in late summer to assess the abundance of juveniles. Surveys are conducted when air temperature is optimal for blunt-nosed leopard lizard activity (25-35 C). When a bluntnosed leopard lizard is observed, attempts are made to capture it with a noose pole. After capturing a lizard, it is sexed, aged, weighed, measured, and uniquely marked by clipping one or more toes before it is released at the capture site. The location of each lizard observed is plotted to determine the effects of disturbance and topographic features on blunt-nosed leopard lizard distribution within each plot.

In May, shrub density and cover of grass, forb, and shrub species were estimated to assess differences between the two monitoring plots and between years on each plot. Six 200-m transects were randomly placed on each study plot. At 5-m intervals, five points were sampled for a total of 200 points per transect. Results were compared between years and monitoring plots using two sample $t$-tests.

\section{RESULTS AND CONCLUSIONS}

\section{Adult Surveys}

Surveys were conducted to assess the abundance of adult blunt-nosed leopard lizards on the two monitoring plots in May and June. There were seven (four females, one male, and two 
unknowns) sightings of adult blunt-nosed leopard lizards on the 4B plot. These observations consisted of four individual females and one individual male. Four lizards (three females and one male) were captured and marked.

More lizards were seen during the 1995 adult surveys although blunt-nosed leopard lizard prey appeared to be less abundant in 1995 than 1996. For example, side-blotched lizards (Uta stansburiana) were observed in 1996, but none in 1995. Furthermore, there were nearly six times more grasshoppers counted on average during adult surveys in 1996 compared to 1995. Despite these facts, in 1995, 20 (10 females and 10 males) adult blunt-nosed leopard lizards were observed on the 4B plot in 1995. The number of individuals observed was four females and four males, of which all but two males were marked.

During adult surveys in both 1995 and 1996, blunt-nosed leopard lizards were seen most frequently in roads and washes where the vegetation is less dense. Dense vegetation may reduce foraging efficiency and also limit blunt-nosed leopard lizards ability to spot and avoid predators.

Blunt-nosed leopard lizards were observed primarily in sparse and patchy vegetation. Mean percent vegetative cover was significantly lower $(t=3.71 ; p<0.01)$ and bare ground was significantly higher $(t=3.35 ; p<0.01)$ in 1996 compared to 1995 (Table 9). Blunt-nosed leopard lizards were not observed on hillsides or in areas of dense vegetation. Such areas probably constitute poor habitat for blunt-nosed leopard lizards.

\section{Juvenile Surveys}

Surveys to assess the abundance of juvenile blunt-nosed leopard lizards were conducted in July and August. In 1996, there were 14 (four adult females, two juvenile females, five juvenile males, and three juvenile unknowns) sightings of blunt-nosed leopard lizards on the 4B plot. Individual lizards observed included two adult female and five juvenile (one female, one male, and three unknowns) blunt-nosed leopard lizards. All were captured and marked with the exception of the three juvenile unknowns.

During 1996 juvenile surveys, over two and a half times as many grasshoppers were observed compared to 1995 . This increase in the abundance of lizard prey may explain why more bluntnosed leopard lizards were sighted during juvenile surveys in 1996 than in 1995. During 1995, there were five (three adult males, one juvenile male, and one juvenile unknown) blunt-nosed leopard lizard observations in 4B. Four (two adult males, one juvenile male, and one juvenile unknown) individual lizards were observed. Only two lizards, an adult male and a juvenile male were marked.

During both 1995 and 1996 juvenile surveys, blunt-nosed leopard lizards were seen much more frequently in sparse vegetation than in patchy or dense vegetation. In 1996, blunt-nosed leopard lizards were seen in roads and washes most often, whereas in 1995 observations were more evenly distributed throughout different physiography types, including roads, flats, and hillsides. 
No blunt-nosed leopard lizards have ever been seen on the $18 \mathrm{G}$ plot. During both 1995 and 1996, mean percent cover was significantly higher (1995: $t=2.78 ; p=0.02 ; 1996: t=5.19 ; p<$ $0.01)$ and bare ground was significantly lower $(1995: t=2.27 ; p<0.05 ; 1996: t=4.39 ; p<$ 0.01 ) on the $18 \mathrm{G}$ monitoring plot than the $4 \mathrm{~B}$ monitoring plot (Table 9). Such densely vegetated habitat may not be suitable for blunt-nosed leopard lizards.

Table 9. Mean percent cover estimated on the blunt-nosed leopard lizard plots, Naval Petroleum Reserve No. 1, Kern County, California, 1995-1996.

\begin{tabular}{|c|c|c|c|c|c|c|c|c|}
\hline \multirow{2}{*}{ Year } & \multirow{2}{*}{ Plot } & \multicolumn{4}{|c|}{ Percent Ground Cover } & \multicolumn{3}{|c|}{ Percent Plant Cover } \\
\hline & & Plant & Litter & $\begin{array}{c}\text { Bare } \\
\text { Ground }\end{array}$ & Crypto & Shrub & Grass & Forb \\
\hline \multirow{2}{*}{1995} & $4 \mathrm{~B}$ & $\begin{array}{l}80.8 \\
(2.8) \\
\end{array}$ & $\begin{array}{c}8.3 \\
(1.5) \\
\end{array}$ & $\begin{array}{l}7.6 \\
(1.5) \\
\end{array}$ & $\begin{array}{l}3.3 \\
(1.0) \\
\end{array}$ & $\begin{array}{l}3.3 \\
(8.9) \\
\end{array}$ & $\begin{array}{l}78.5 \\
(4.3)\end{array}$ & $\begin{array}{l}18.3 \\
(4.8)\end{array}$ \\
\hline & $18 \mathrm{G}$ & $\begin{array}{l}89.5 \\
(1.4) \\
\end{array}$ & $\begin{array}{c}6 \\
(0.8) \\
\end{array}$ & $\begin{array}{l}3.4 \\
(1.0) \\
\end{array}$ & $\begin{array}{l}1.1 \\
(0.8) \\
\end{array}$ & $\begin{array}{l}4.6 \\
(2.0) \\
\end{array}$ & $\begin{array}{l}77.1 \\
(2.7) \\
\end{array}$ & $\begin{array}{r}18.4 \\
(1.7) \\
\end{array}$ \\
\hline \multirow[b]{2}{*}{1996} & 4B & $\begin{array}{l}60.0 \\
(4.8) \\
\end{array}$ & $\begin{array}{c}14 \\
(1.3) \\
\end{array}$ & $\begin{array}{l}24.6 \\
(4.8) \\
\end{array}$ & $\begin{array}{c}1.4 \\
(0.4) \\
\end{array}$ & $\begin{array}{l}1.6 \\
(1.1) \\
\end{array}$ & $\begin{array}{l}85.7 \\
(1.5) \\
\end{array}$ & $\begin{array}{r}13.7 \\
(1.6) \\
\end{array}$ \\
\hline & $18 \mathrm{G}$ & $\begin{array}{l}85.9 \\
(1.2)\end{array}$ & $\begin{array}{l}10.8 \\
(1.2)\end{array}$ & $\begin{array}{l}3.1 \\
(0.8)\end{array}$ & $\begin{array}{c}0.3 \\
(0.1)\end{array}$ & $\begin{array}{l}6.9 \\
(2.6)\end{array}$ & $\begin{array}{l}91.5 \\
(2.5)\end{array}$ & $\begin{array}{c}1.6 \\
(0.7)\end{array}$ \\
\hline
\end{tabular}

\subsection{HOOVER'S WOOLY-STAR POPULATION MONITORING}

\section{INTRODUCTION}

The ecological status of Hoover's wooly-star, Eriastrum hooveri, is evaluated annually by monitoring six of approximately 310 known Hoover's wooly-star colonies on NPR-1. Permanent reference monitoring plots were established on six colonies in 1993 to monitor changes in Hoover's wooly-star density and habitat over time. Two of the plots are located on the lower slopes of the south flank of the Elk Hills formation (Sections 12B and 17G), two are near the crest (Sections 33R and 33S), and two are on the lower slopes of the north flank (Sections 20S and 7R). 


\section{METHODS AND MATERIALS}

Density and cover of Hoover's wooly-star and associated grass, forb, and shrub species were measured on the plots in April and May 1996. These data were gathered along three permanent linear transects located within each reference plot. All data were proofed and entered into a Paradox 4.0 database and summarized. Precipitation data from the Bakersfield Airport, Bakersfield, California, was derived from monthly reports published by the National Climatic Data Center.

\section{RESULTS}

In 1996, Hoover's wooly-star density ranged from $0-0.7 / \mathrm{m}^{2}$ on the six reference plots and averaged $0.3 / \mathrm{m}^{2}(\mathrm{SE}=0.1$ ) (Figure 6). Hoover's wooly-star frequency of occurrence ranged from 0 to $24.0 \%$ using square meter sampling frames and averaged $8.8 \%(\mathrm{SE}=2.8)$. Hoover's wooly-star density and frequency were lower than 1995 levels, probably in part due to a corresponding decrease in precipitation prior to and during the growing season. October through March precipitation, the primary months that precipitation is believed to contribute to spring growth of annual plants, was $227 \mathrm{~mm}$ for the 1995 growing season and $163 \mathrm{~mm}$ for the 1996 growing season (Figure 6). Although precipitation contributing to the 1996 growing season was above the 30-year normal of $123 \mathrm{~mm}, 1996$ was generally a poor year for forb germination and survival, including Hoover's wooly-star.

In 1996, shrub cover on the six reference plots averaged $8.1 \%(\mathrm{SE}=2.0)$, grass cover averaged $52.3 \%$ ( $\mathrm{SE}=3.2$ ), and forb cover averaged $1.1 \%(\mathrm{SE}=0.4$ ) (Table 10$)$. Total vascular plant cover averaged 61.4\% (SE = 3.7). The decrease in forb cover between 1995 and 1996 was disproportional to the decrease in October through March precipitation. 


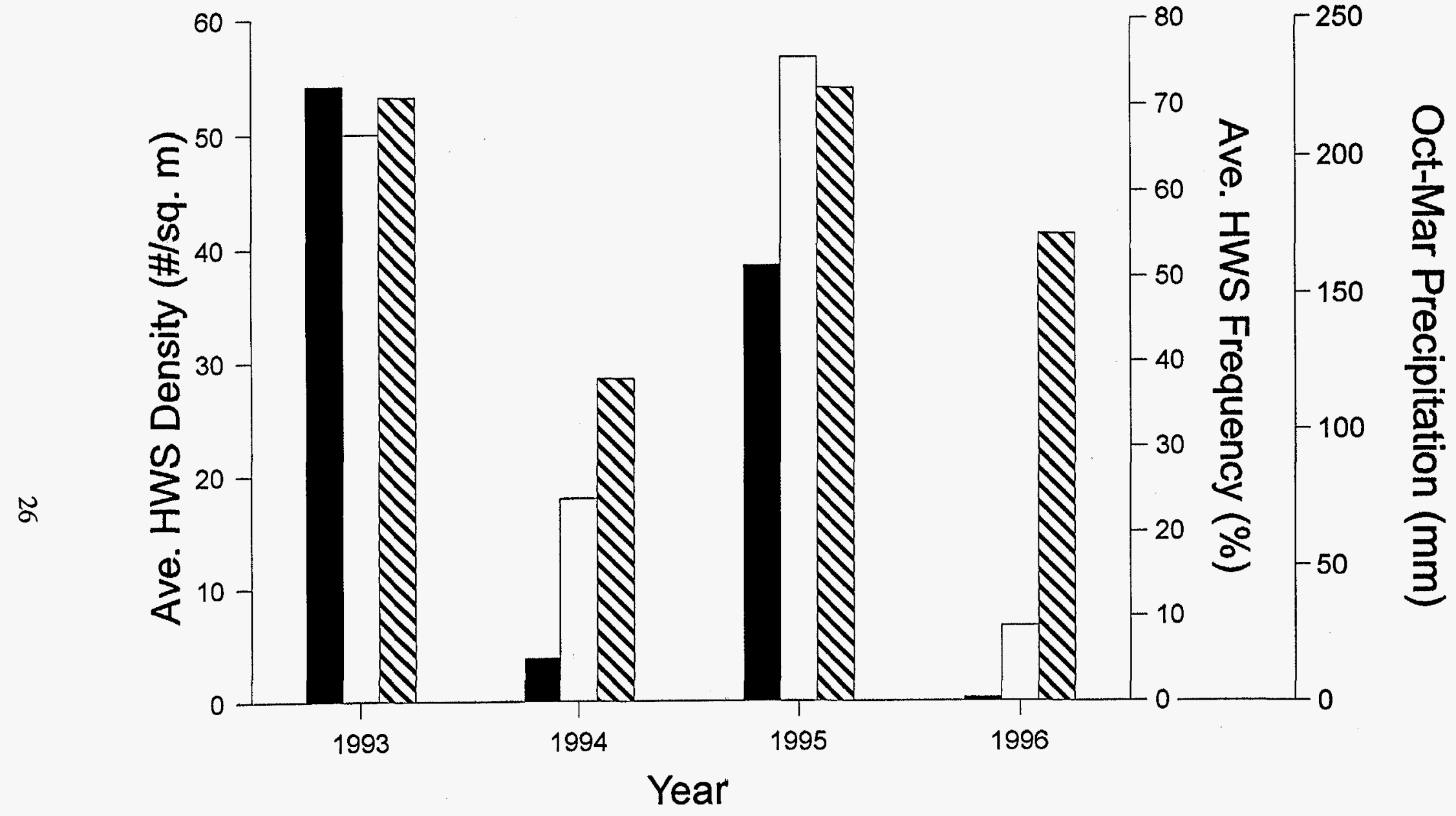

$\square$ Density $\square$ Frequency $\quad$ IIV Precipitation

Figure 6. Average Hoover's wooly-star density, frequency of occurrence, and October through March precipitation on permanent reference plots, Naval Petroleum Reserve No. 1, Kern County, California, 1993-1996. 
Table 10. Total vascular plant cover by lifeform on Hoover's wooly-star reference plots on Naval Petroleum Reserve No. 1, Kern County, California, 1993-1996. Standard errors are in parentheses.

\begin{tabular}{||c|c|c|c|c|c||}
\hline \multirow{2}{*}{$\begin{array}{c}\text { Growing } \\
\text { Season }\end{array}$} & \multicolumn{4}{|c|}{ Average Vascular Plant Cover (\%) } & \multirow{2}{*}{$\begin{array}{c}\text { PPT }^{\mathrm{a}} \\
\text { (mm) }\end{array}$} \\
\cline { 2 - 5 } & Shrub & Grass & Forb & Total & \\
\hline \hline 1993 & $5.3(3.30)$ & $35.8(7.10)$ & $21.9(3.90)$ & $63.2(3.19)$ & 224 \\
\hline 1994 & $4.1(1.06)$ & $15.6(2.20)$ & $3.9(1.12)$ & $22.2(3.38)$ & 113 \\
\hline 1995 & $7.9(1.83)$ & $45.6(2.78)$ & $16.6(1.75)$ & $70.1(2.53)$ & 227 \\
\hline 1996 & $8.1(2.03)$ & $52.3(3.24)$ & $1.1(0.36)$ & $61.4(3.73)$ & 163 \\
\hline $\begin{array}{c}\text { Overall } \\
\text { Average }\end{array}$ & 6.4 & 37.3 & 10.9 & 54.2 & $123^{\mathrm{b}}$ \\
\hline
\end{tabular}

actober through March precipitation; precipitation contributing to current year's growth of annual plants.

${ }^{b}$ Thirty-year average of October through March precipitation.

\section{CONCLUSIONS}

The data support the conclusion that Hoover's wooly-star is highly sensitive to precipitation level changes (Figure 6). However, temperature patterns, relative humidity, and the timing of major precipitation events may also play keys roles in the germination of Hoover's wooly-star seeds. Variation in these climatological factors may help explain the lower Hoover's wooly-star densities and frequencies observed in 1996.

\subsection{ASSESSMENT OF SPECIAL STATUS PLANT SPECIES}

\section{INTRODUCTION}

Surveys for special status plant species on NPR-1 were completed in late March and early April 1996. The comprehensive, systematic survey of NPR-1 for special status plants was initiated in spring 1995 . That year, approximately 1,685 ha $(4,160 \mathrm{ac})$ were surveyed along the northern edge of NPR-1 (Figure 7). In 1996, only 648 ha $(1,600 \mathrm{ac})$ were surveyed due to low forb numbers observed during the initial part of the survey (Figure 7). Table 11 lists 37 special status species targeted during the surveys. Federal or State listed plants occurring near NPRC and rare plants identified by the California Native Plant Society were included in the list of target plants. 


\section{METHODS AND MATERIALS}

Two types of areas were given priority during the 1996 surveys: (1) areas having habitat likely to support special status plants, and (2) areas likely to be impacted by exploration or development activities in the near future. Section 10B consisting of 259 ha $(640 \mathrm{ac})$ was selected based on the first criterion. The remaining $389 \mathrm{ha}(960 \mathrm{ac})$ were identified as areas of future development.

Prior to surveying, field personnel attended a one-day course on identifying local common and special status plants, specimen collecting methods, and field surveying and recording methods. Survey methods consisted of searching for species listed in Table 11 while walking north-south oriented, $0.8-\mathrm{km}(0.5$-mile) long transects spaced at $30.5-\mathrm{m}$ (100-foot) intervals. Transect direction was maintained using hand-held compasses in combination with sighting poles or pin flags placed at ends of transects. Observations were recorded on $1.5-\mathrm{m}$ (5-foot) contour interval topographical maps. Specimens of special status plants were collected from most new occurrences, pressed, and dried. Plants of the Stylocline and Filago genera were sent to a species expert for identification verification.

Occurrences from 1995 and 1996 surveys were digitized and mapped by Bechtel Petroleum Operations, Inc. (BPOI) personnel using AutoCAD. Digitized data were overlaid onto 6.1-m (20foot) contour interval topographical base map files. New occurrence records will be sent to the California Department of Fish and Game (CDFG) for inclusion in the California Natural Diversity Data Base. 
7R. Section number and township label

Areas surveyed for special status plants in 1995

Areas surveyed for special status plants in 1996

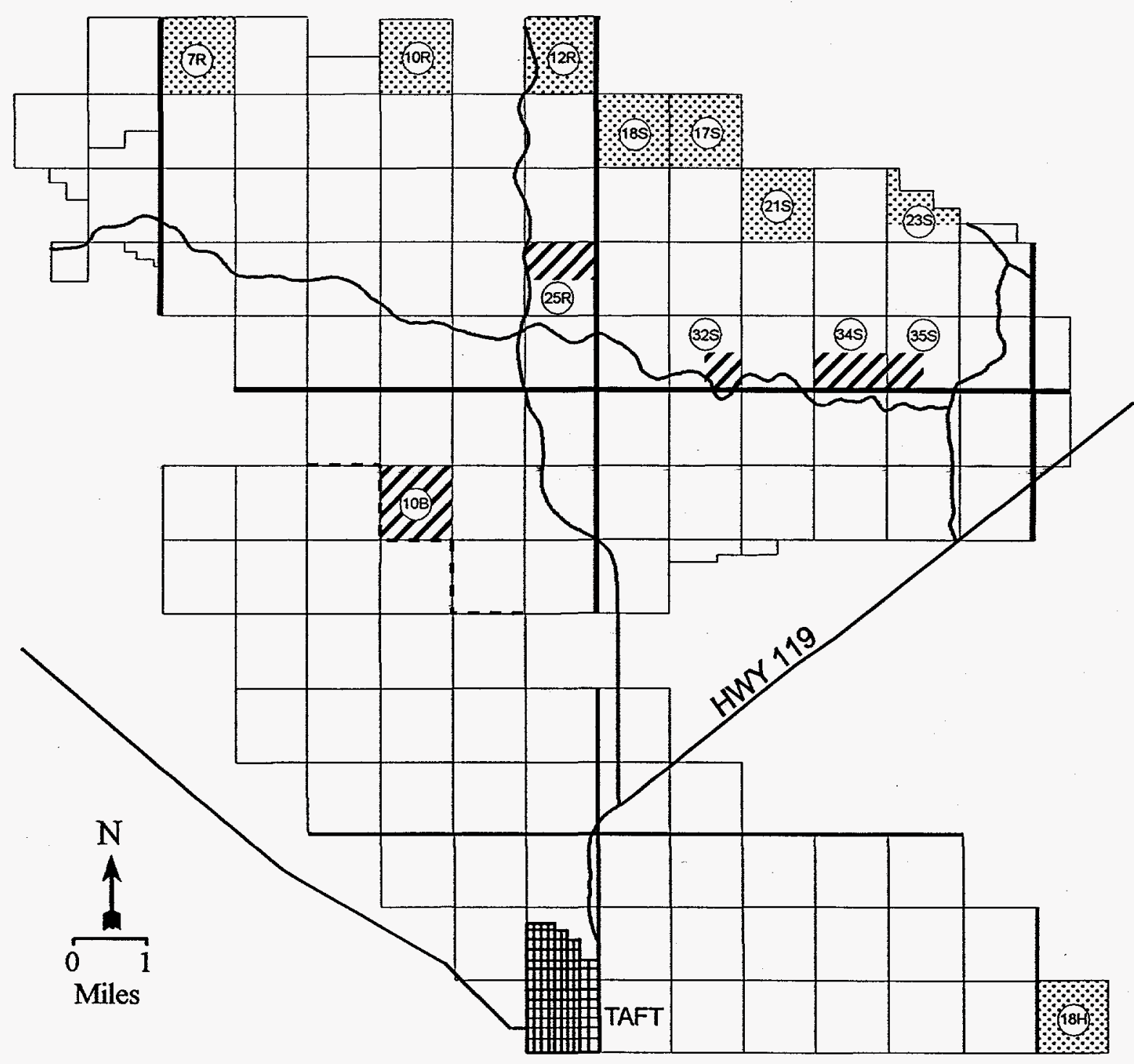

Figure 7. Areas surveyed for special status plants at Naval Petroleum Reserves in California, Kern County, California, 1995-1996. 
Table 11. Floristic survey target species, Naval Petroleum Reserve No. 1, Kern County, California, 1996.

\begin{tabular}{|c|c|c|c|}
\hline Scientific Name & Common Name & $\begin{array}{l}\text { Protective } \\
\text { Status }\end{array}$ & $\begin{array}{c}\text { Apparent Relative } \\
\text { Abundance at } \\
\text { NPRC }\end{array}$ \\
\hline \multicolumn{4}{|c|}{ SPECIES KNOWN TO OCCUR ON NPRC } \\
\hline Atriplex coronata var. coronata & crownscale & CNPS List 4 & common \\
\hline $\begin{array}{l}\text { Delphinium gypsophilum spp. } \\
\text { gypsophilum }\end{array}$ & gypsum-loving larkspur & CNPS List 4 & common \\
\hline Delphinium recurvatum & recurved larkspur & CNPS List 1B & rare \\
\hline Eriastrum hooveri & Hoover's wooly-star & $\mathrm{FT}^{\mathrm{a}}$ & common \\
\hline Eriogonum gossypinum & cottony buckwheat & CNPS List 4 & uncommon \\
\hline Hollisteria lanata & hollisteria & None & uncommon \\
\hline Larrea tridentata & creosotebush & & rare \\
\hline Stylocline citroleum & oil nest straw & CNPS List 1B & uncommon \\
\hline Trichostema ovatum & San Joaquin bluecurls & CNPS List 4 & common \\
\hline \multicolumn{4}{|c|}{ SPECIES POSSIBLY OCCURRING ON NPRC } \\
\hline $\begin{array}{l}\text { Amsinckia vernicosa var. } \\
\text { furcata }\end{array}$ & forked fiddleneck & CNPS List 4 & unknown \\
\hline Atriplex cordulata & heartscale & CNPS List 1B & unknown \\
\hline Caulanthus californicus & California jewelflower & $\mathrm{FE}^{\mathrm{b}}, \mathrm{CE}^{\mathrm{c}}$ & unknown \\
\hline Cirsium crassicaule & slough thistle & CNPS List 1B & unknown \\
\hline Eremalche kernensis & Kern mallow & FE & unknown \\
\hline Eriogonum temblorense & Temblor buckwheat & CNPS List 4 & unknown \\
\hline $\begin{array}{l}\text { Eschscholzia lemmonii spp. } \\
\text { kernensis }\end{array}$ & Tejon poppy & CNPS List 1B & unknown \\
\hline Lembertia congdonii & San Joaquin wooly-threads & FE & unknown \\
\hline Stylocline masonii & Mason's nest straw & CNPS List 1B & unknown \\
\hline
\end{tabular}




\begin{tabular}{||l|l|l|l||}
\hline \multicolumn{4}{|l|}{ SPECIES HIGHLY UNLIKELY TO OCCUR ON NPRC } \\
\hline Androsace elongata ssp. acuta & California androsace & CNPS List 4 & absent \\
\hline Antirrhinum ovatum & oval-leaved snapdragon & CNPS List 4 & absent \\
\hline Atriplex depressa & brittlescale & CNPS List 1B & absent \\
\hline Atriplex joaquiniana & San Joaquin spearscale & CNPS List 1B & absent \\
\hline Atriplex minuscula & lesser saltscale & CNPS List 1B & absent \\
\hline Atriplex tularensis & Bakersfield saltbush & CE & absent \\
\hline Atriplex vallicola & Lost Hills saltbush & CNPS List 1B & absent \\
\hline Calochortus striatus & alkali mariposa & CNPS List 1B & absent \\
\hline Chorizanthe spinosa & Mojave spineflower & CNPS List 4 & absent \\
\hline $\begin{array}{l}\text { Clarkia tembloriensis ssp. } \\
\text { calientensis }\end{array}$ & Vasek's clarkia & FC & absent \\
\hline $\begin{array}{l}\text { Cordylanthus mollis ssp. } \\
\text { hispidus }\end{array}$ & hispid bird's-beak & CNPS List 1B & absent \\
\hline Cordylanthus palmatus & palmate-bracted bird's-beak & FE, CE & absent \\
\hline Eschscholzia rhombipetala & $\begin{array}{l}\text { diamond-petaled California } \\
\text { poppy }\end{array}$ & CNPS List 1A & absent \\
\hline Hordeum intercedens & vernal barley & CNPS List 3 & absent \\
\hline Layia heterotricha & pale-yellow layia & CNPS List 1B & absent \\
\hline Layia leucopappa & Comanche Point layia & FC & absent \\
\hline Layia munzii & Munz's tidy tips & CNPS List 1B & absent \\
\hline Lepidium jaredii spp. jaredii & Jared's peppergrass & CNPS List 1B & absent \\
\hline Madia radiata & showy madia & CNPS List 1B & absent \\
\hline
\end{tabular}

${ }^{a}$ Listed as federal threatened species under the federal Endangered Species Act.

${ }^{b}$ Listed as federal endangered species under the federal Endangered Species Act.

${ }^{c}$ Listed as California endangered species under the California Endangered Species Act.

${ }^{\mathrm{d}}$ Federal candidate for listing under the federal Endangered Species Act. 


\section{RESULTS}

Atriplex coronata was observed in Sections $32 \mathrm{~S}$ and 34S. Eriastrum hooveri was observed in all of the areas surveyed and was most abundant in Section 10B, the least hilly area surveyed (Figure 7). Eriogonum gossypinum was observed in Sections 10B, 25R, 32S, and 34S. A known occurrence of Larrea tridentata, a rare species in the southern San Joaquin Valley, was revisited in Section 10B. Specimens of Stylocline citroleum $(n=143)$, a species formerly only known to exist at four locations on the north flank of the Elk Hills formation, were collected and verified from 22 locations. Stylocline citroleum was found in Sections 10B, 25R, and 35S. The species was also observed just outside of the survey area in Section $3 \mathrm{G}$ and was found incidental to this study in Sections 14R and 14G (not shown). No other special status plants were encountered.

\section{CONCLUSIONS}

Although 1996 was generally a poor year for forb germination and survival and less acreage was surveyed than planned, valuable information was gathered on the occurrence of several special status plant species at NPR-1. Eriastrum hooveri was found to be common on flatter terrain and on bare, open ridge tops such as in Section 10B. Stylocline citroleum was discovered in the steeper hills and on the south flank of the Elk Hills formation. Previously undocumented occurrences of $A$. coronata and $E$. gossypinum were discovered. Locational data were digitized for future incorporation into a GIS. Surveys will continue to be conducted for special status plants on NPR-1 during years of normal or above normal precipitation until NPR-1 is completely surveyed. This information will contribute to the conservation and recovery of these species. 


\section{CONDUCT PREACTIVITY SURVEYS FOR NPRC PROJECTS}

\subsection{CONDUCT ENDANGERED SPECIES AND CULTURAL RESOURCE PREACTIVITY SURVEYS}

\section{INTRODUCTION}

The preactivity survey program was developed to minimize or eliminate impacts of petroleumrelated activities to endangered species and their habitats as well as cultural resources on NPRC. Preactivity surveys are conducted for all projects resulting in habitat disturbance.

\section{METHODS AND MATERIALS}

Preactivity survey requests are forwarded to EASI by BPOI. During preactivity surveys a biologist examines the anticipated impact area and an adjacent buffer zone for evidence of threatened and endangered species. Specifically, the biologist looks for known San Joaquin kit fox dens, potential kit fox dens, giant kangaroo rat burrows, blunt-nosed leopard lizards, washes representing potential blunt-nosed leopard lizard habitat, and Hoover's wooly-star. Observed kit fox dens, giant kangaroo rat burrows, blunt-nosed leopard lizard habitat, and some populations of Hoover's wooly-star are then identified with wooden stakes and flagging to create avoidance zones consistent with those specified in the 1995 Biological Opinion for petroleum production on NPR-1. Once the preactivity survey has been completed, the biologist contacts the requestor to report any findings and make recommendations to refrain from disturbing the area marked.

Follow-up surveys are conducted, usually within three months of the original survey, to document whether endangered species or their habitat were impacted, recommendations were followed, and activities were confined to the surveyed project area. Recommendations that are not followed are reported in a monthly summary letter that is sent to requestors.

\section{RESULTS AND CONCLUSIONS}

During FY96, 1,596 preactivity surveys were conducted on 639 ha $(1,579 \mathrm{ac})$ on or adjacent to NPRC (Table 12). Of these, 184 surveys were classified as emergencies (projects requiring a preactivity survey within three working days). Most emergency surveys were conducted for cleanups, pipelines, new well pads, and other miscellaneous construction projects. Compared with FY95, 922 more surveys were conducted in FY96 (approximately a 137\% increase). The average for emergency surveys in FY96 was 12\%, compared to $16 \%$ in FY95.

Recommendations to prevent potential impacts to endangered species or their habitats were made on a total of 193 projects in FY96. New well pads, pipelines, and other miscellaneous construction or maintenance projects were most often affected. Alterations usually included the establishment of avoidance zones around dens and burrows, restriction of driving on revegetated 
sites and in washes, and establishment of avoidance zones around populations of Hoover's woolystar. Most cleanup sites were restricted to the use of hand tools only.

A total of seven known kit fox dens and 56 potential kit fox dens were identified during surveys in FY96. Six washes representing potential blunt-nosed leopard lizard habitat were identified and two blunt-nosed leopard lizards were observed. At 71 survey sites, populations of Hoover's wooly-star were identified. Evidence of giant kangaroo rats was found at 25 survey sites.

All resources were avoided except for the excavation of one potential kit fox den and several giant kangaroo rat burrows located at new well pad sites. Prior to excavation, all dens were monitored for three consecutive nights to assess if the dens were being used by kit foxes. No wildlife was found in any of the excavated dens.

Follow-up surveys were conducted on all of the projects where evidence of endangered or threatened species, their habitats, or revegetated areas were encountered during the initial preactivity survey. In addition, follow-up surveys were conducted for most cleanups and some survey areas where no endangered species were found, but where there were causes for concern. During 256 follow-up surveys, it was found that recommendations were not followed on three projects completed in FY96. These incidents did not result in any take of listed species, and operators and their supervisors were contacted to correct the problems.

In FY96, EASI participated in an effort to streamline maintenance of wellpads by allowing clearing or blading of established wellpads to be done without surveys. After the work was completed the sites were visited to verify that no adverse impacts occurred. 
Table 12. Summary of endangered species and cultural resource preactivity surveys conducted during FY96 on the Naval Petroleum Reserves in California, Kern County, California.

\begin{tabular}{|c|c|c|}
\hline Type of Disturbance & Number of Surveys & Number of Acres \\
\hline Cleanups & 136 & 80 \\
\hline Pipeline & 95 & 107 \\
\hline $\begin{array}{l}\text { Well Pads } \\
\text {-New } \\
\text {-Regrade }\end{array}$ & $\begin{array}{c}39 \\
4 \\
\end{array}$ & $\begin{array}{c}91 \\
2\end{array}$ \\
\hline Powerlines & 42 & 44 \\
\hline Corrosion Protection & 9 & 8 \\
\hline Other $^{\mathrm{a}}$ & 1,271 & 1,247 \\
\hline Totals & 1,596 & 1,579 \\
\hline
\end{tabular}

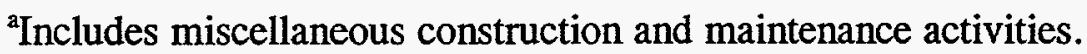

\subsection{THIRD-PARTY PROJECTS}

Non-NPRC organizations occasionally conduct construction projects that cross a portion of NPR-1 or government lands on NPR-2. These projects are classified as third-party projects. EASI assists NPRC in ensuring that such projects comply with federal regulations pertaining to endangered species and cultural resources. Such assistance usually consists of reviewing biological and archaeological assessments prepared by third party proponents or their consultants to ensure that these documents are consistent with NPRC policies and requirements regarding protection of listed species and cultural resources. EASI also facilitates consultations with FWS or the State Historic Preservation Officer (SHPO) on behalf of the third party. The cultural resource activity results are described in Section 3.4.

In FY96, EASI reviewed preactivity survey results and proposed mitigation actions for a pipeline proposed by Holmes Western Oil Corporation on NPR-2. EASI also reviewed preactivity survey results and proposed mitigation actions for a new communication line and a new well proposed by Chevron on NPR-2. EASI reviewed and commented on biological and archaeological assessments for three new wells proposed by Vintage Oil Company on NPR-2. Assistance was provided on initiating formal consultations with FWS and SHPO for this project. EASI reviewed and commented on a proposed lease transfer on NPR-2 for Nuevo Energy Company. Finally, EASI reviewed a supplemental biological assessment for a well on NPR-2 proposed by CPDN as part of their on-going $\mathrm{CO}_{2}$ flood project. 


\subsection{CULTURAL RESOURCES SUPPORT}

\section{INTRODUCTION}

Prehistoric and historic cultural resources at NPRC are protected under the NHPA of 1966 (as amended) and other federal acts and executive orders. Section 110 of the Act requires federal agencies to establish programs to locate, inventory, and nominate historic properties under the agencies' control. Section 106 of the Act requires federal agencies to take into account the effect of federal undertakings on historic properties. In 1990, a program for identifying, protecting, and managing cultural resources at NPRC was established and EG\&G Energy Measurements, Inc. was named DOE/NPRC's designated representative for cultural resources. In FY96, DOE/NPRC transferred the cultural resources program contract and "representative for cultural resources" designation to EASI.

\section{METHODS AND MATERIALS}

To comply with sections 106 and 110 , qualified archaeologists are contracted to conduct surveys of cultural resources for large DOE/NPRC projects and for all third party projects. Surveys for smaller, routine projects at NPRC are conducted by EASI archaeologists or by other environmental field personnel who have received training from qualified archaeologists on the detection and identification of cultural resources common to the southern San Joaquin Valley. Survey results are compiled and effects on cultural resources assessed. Reports containing this information are sent to SHPO for review. During FY96, EASI continued to maintain DOE/NPRC's cultural resources data base and collections and responded to cultural resource related requests.

\section{RESULTS AND CONCLUSIONS}

The cultural resource projects conducted in 1996 are summarized in Table 13. The Center for Archaeological Research was contracted to conduct a cultural resources study of the Western NPR-1 3-D Program area. Field work was completed in January 1996. Three prehistoric and 22 historic archaeological sites were recorded, for a total of 25 sites. For expediency, DOE/NPRC elected to avoid all sites rather than evaluate sites with undetermined eligibility. The assessment report was completed in early March. On March 7, DOE/NPRC transmitted the report along with its finding of "no effect" to SHPO for comments. SHPO concurred with the content of the report and with the "no effect" determination on April 17, 1996.

Three Girls and a Shovel, a consulting firm, was contracted by Vintage Petroleum Inc. to conduct a survey for three proposed well locations on NPR-2. Field work was conducted on May 1, 1996. No resources were found and no further archaeological work was recommended. On June 10, 1996, DOE/NPRC transmitted the report along with its finding of "no effect" to SHPO. No comments were received from SHPO. 
The Center for Archaeological Research was contracted to conduct a survey for DOE/NPRC's proposed cleanup of a residential trash dump on NPR-2 in Ford City, California. Field work was conducted on June 14, 1996. Due to its low integrity and lack of primary context, the trash dump was not recorded as a site. A letter report was sent by DOE/NPRC to SHPO with the results and a finding of "no effect" on September 12. No comments were received from SHPO.

At DOE/NPRC's request, EASI reviewed and commented on draft revisions to 36 Code of Federal Regulations Part 800, implementing regulations for the NHPA (as amended).

Table 13. Summary of FY96 cultural resource identification and assessment activities on the Naval Petroleum Reserves in California, Kern County, California.

\begin{tabular}{||l|l|l|c|c|l||}
\hline Survey Date & \multicolumn{1}{|c|}{ Project } & Area & $\begin{array}{c}\# \\
\text { Arch. } \\
\text { Sites }\end{array}$ & $\begin{array}{c}\# \\
\text { Isolates }\end{array}$ & \multicolumn{1}{|c||}{ SHPO $^{\text {Response }}$} \\
\hline $\begin{array}{l}\text { Nov. 1995 - } \\
\text { Jan. 1996 }\end{array}$ & $\begin{array}{l}\text { DOE Western } \\
\text { NPR-1 3-D } \\
\text { Seismic Program }\end{array}$ & $\begin{array}{l}\text { Western } \\
\text { NPR-1 } \\
(14 \text { miles) }\end{array}$ & 25 & 4 & $\begin{array}{l}\text { Received } \\
\text { concurrence with a } \\
\text { finding of "no } \\
\text { effect" on 04/17/96 } \\
\text { (DOE951024B) }\end{array}$ \\
\hline May 1996 & $\begin{array}{l}\text { Vintage Petroleum } \\
\text { 3 Proposed Wells }\end{array}$ & Section 20B & 0 & 0 & None \\
\hline June 1996 & $\begin{array}{l}\text { Ford City Trash } \\
\text { Dump }\end{array}$ & Section 12C & 0 & 0 & None \\
\hline
\end{tabular}

${ }^{a}$ California State Historic Preservation Officer

\subsection{WESTERN NPR-1 3-D SEISMIC PROGRAM}

\section{INTRODUCTION}

From March 1996 through the end of FY96, preparations were being made for a 3-D seismic survey of the western part of NPR-1, Kern County, California (Figure 8). The purpose of the survey is to determine the potential for presence of hydrocarbon deposits in an approximately 18$\mathrm{km}^{2}\left(7\right.$ mile $\left.{ }^{2}\right)$ target area within a $36-\mathrm{km}^{2}(14$ mile $)$ survey activity area.

The survey will provide information on recoverable reserves at NPR-1, and reduce the risks and costs associated with further exploration and development in the area. The project area includes DOE/NPRC, Bureau of Land Management (BLM)-administered lands, one CDFG parcel, CPDN 
lands, and other private lands both on and off of NPR-1. Seismic survey field activities consist of: Phase 1 - geodetic surveying, Phase 2 - drilling about 692115 -mm diameter, 99 to $221-\mathrm{m}$ (325 to 725-foot) deep shotholes, and loading and backfilling explosive charges in the holes, Phase 3 - stringing receiver lines connecting geophone arrays, sequentially detonating the charges, and recording the reflected energy, and Phase 4 - cleanup, recontouring, and habitat reclamation. Biologists with EASI are providing endangered species and cultural resources compliance support services for all four phases of the project and will prepare a post-activity compliance report.

\section{METHODS AND MATERIALS}

While planning the project, DOE/NPRC recognized the potential for impacts to threatened or endangered species and cultural resources. In cooperation with BLM, a cultural resource field study was conducted and a draft Joint Environmental Assessment (EA) evaluating impacts to these and other resources was prepared. A cultural resource assessment was sent to SHPO, and SHPO concurred with a "no effect" finding on April 17, 1996 (see Section 3.3). CDFG Fresno Regional Office staff verbally concurred with the 2081 permit on May 1, 1996. Compliance coordination was conducted with FWS, and NPRC determined that the seismic survey was covered under the November 8, 1995 Biological Opinion for NPR-1

Geodetic surveying (Phase 1) began on April 18 and ended May 13, 1996. Surveyors and other project personnel were briefed by EASI environmental monitors on the occurrence of sensitive resources in the project area and given fact sheets summarizing draft environmental permit requirements. Archaeological sites, San Joaquin kit fox dens, giant kangaroo rat precincts, bluntnosed leopard lizards, and other resources requiring avoidance were flagged. In coordination with geodetic surveyors, EASI environmental monitors conducted 60-day biological preactivity surveys of all proposed shothole locations and access routes. EASI staff assisted project personnel in relocating a number of proposed access routes and several shotholes to avoid sensitive biological resources, several archaeological sites, and a historic railroad grade.

Shothole drilling (Phase 2) began on May 17 and was 60\% completed at the end of FY96. Drilling personnel were briefed and received environmental fact sheets. EASI environmental monitors conducted 60-day and 24-hour biological preactivity surveys ahead of drilling crews as needed. EASI staff continued to assist in the relocation of proposed access routes and shotholes and gave recommendations on how to minimize habitat disturbance. Environmental monitors observed drilling crew and water truck activities to evaluate compliance with draft permit requirements. Weekly safety and daily project coordination meetings were attended. EASI staff provided daily lists of approved shotholes to the drillers and continually updated drill site access maps. Cumulative temporary disturbance was measured and reported weekly to BPOI and DOE/NPRC. 


\section{RESULTS}

As of the end of FY96, all archaeological sites and the historic railroad grade were successfully avoided. With few exceptions, sensitive biological resources were successfully avoided through a cooperative effort on the part of DOE/NPRC, BPOI, EASI environmental monitors, and seismic contractor personnel.

As of the end of FY96, a minimum of $18.3 \mathrm{ha}(45.2 \mathrm{ac})$ had been temporarily disturbed as a result of project activities. The total temporary disturbance at the end of the project was projected to be about 38.1 ha $(94.0 \mathrm{ac})$. No direct take of threatened or endangered species was observed. Four areas with the federal threatened Hoover's wooly-star were impacted by vehicles following seed dispersal. A total of approximately 79 Hoover's wooly-star skeletons were present on the sites. Vegetation was crushed in these areas and soils became powdery in several places. Effects on the Hoover's wooly-star seed bank are unknown, but are believed to be minimal. Seed bank salvage was not implemented because it would have disturbed the habitat more than project vehicles had. Due to the lack of a suitable alternate site for a shothole, one potential kit fox den required monitoring and excavation.

\section{CONCLUSIONS}

A minimum of 18.3 ha have been temporarily disturbed as a result of project activities. A total of approximately 38.1 ha is projected by the end of the project. To date, no direct take of threatened or endangered species has been observed or attributed to the Western NPR-1 3-D seismic program. EASI will continue to provide environmental support services until the project is completed. Preactivity survey results, monitoring observations and non-compliance incidents will be described in more detail in a post-activity compliance report. 


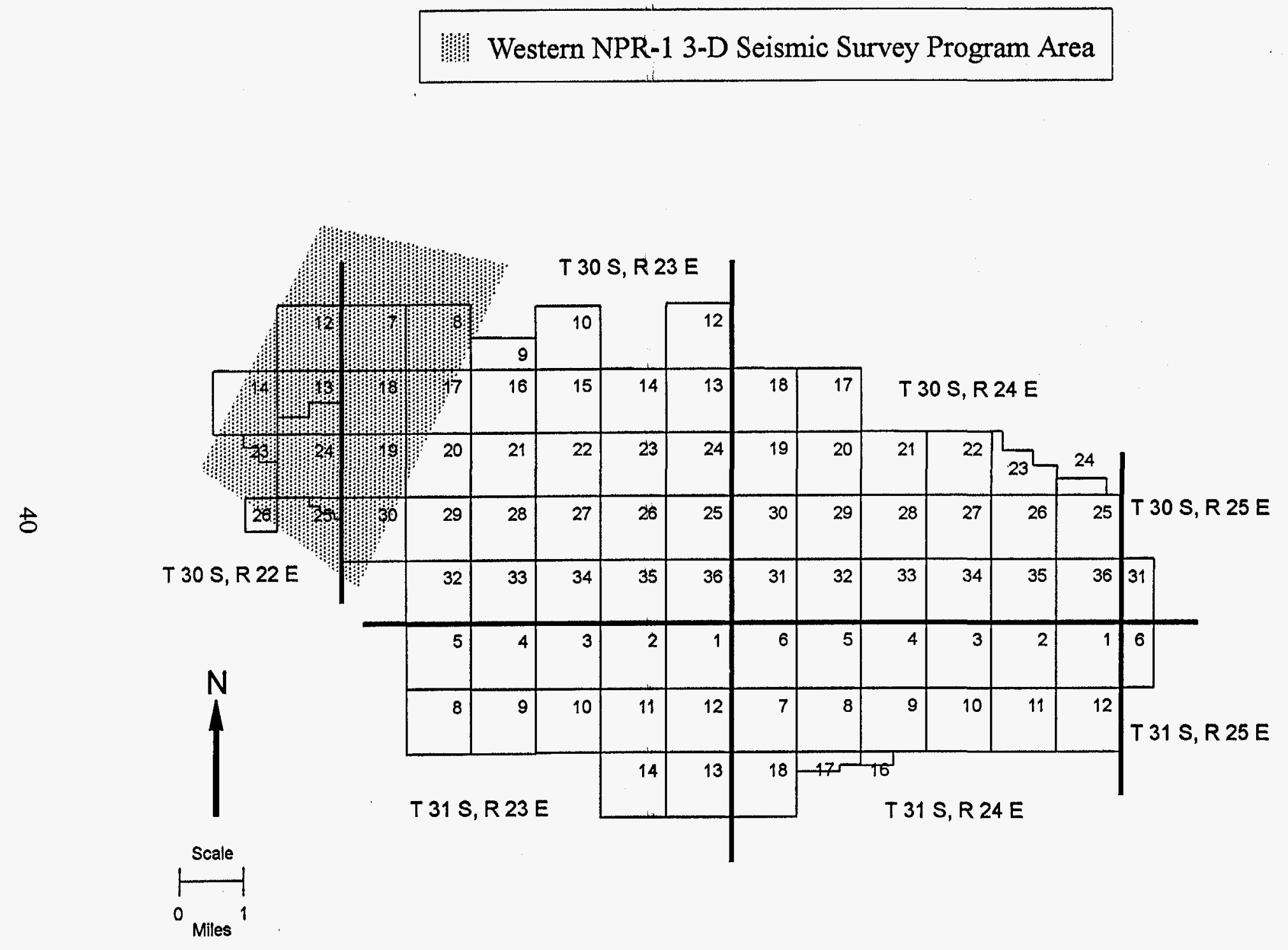

Figure 8. Map depicting Western Naval Petroleum Reserve No. 1 3-D Seismic Survey Program area, Naval Petroleum Reserve No: 1, Kern County, California, 1996. 


\section{HABITAT RECLAMATION AND MANAGEMENT}

\subsection{MONITORING RECLAMATION SUCCESS}

\section{INTRODUCTION}

The success of the habitat reclamation program at NPRC has been monitored since 1987. Vegetation on reclaimed sites was originally monitored by evaluating quantitative vegetation measurements taken at each site. As the number of reclaimed sites continued to increase, a combination of quantitative and qualitative sampling methods was adopted. In 1991, 16 vegetation reference sites were established throughout NPR-1. Quantitative data on vegetation at the sites were averaged according to aspect (north slope, south slope), then used as indices of sitewide vegetation characteristics. Sites were considered successfully reclaimed when vegetative cover and shrub density was $70 \%$ or more of the cover and density on the reference sites. Since 1994, evaluating success of habitat reclamation has been accomplished by qualitatively comparing vegetative cover on sites reclaimed ten years previous to cover on undisturbed adjacent areas. Sites are deemed successfully reclaimed when vegetative cover is $>70 \%$ of the cover observed on adjacent undisturbed areas.

\section{METHODS AND MATERIALS}

In 1996, a 30\% sample of sites reclaimed in 1986 was randomly selected from a pool of 218 sites available for sampling. Sites were qualitatively monitored. Samples were chosen in proportion to the number of different disturbance types represented in the pool (cut/fill slopes, well pads, roads, pipelines, and borrow areas). Qualitative estimations were calibrated by post hoc comparison of visual estimates of percent vascular plant cover, litter and bare ground to quantitative measurements of these same variables at 10 small mammal monitoring plots. Qualitative estimations were adjusted by comparing qualitative estimation results for a plot with the actual quantitative results. Following researcher calibration, percent cover of vascular plants, litter, bare ground, and cover by lifeform were estimated at 66 sites. Total vascular plant cover was estimated on a representative undisturbed site adjacent to each reclamation site. Evidence of use by wildlife was recorded.

\section{RESULTS}

Total vascular plant cover averaged $63.4 \%(\mathrm{SE}=2.5)$ for the sample of sites $(\mathrm{n}=66)$ reclaimed in 1986 (Table 14). Litter cover averaged 6.2\% ( $\mathrm{SE}=0.8)$ and bare ground cover averaged $30.6 \%$ ( $\mathrm{SE}=1.7$ ). Shrubs, grasses and forbs comprised an average of $21.5 \%$ (SE = 1.7), $71.7 \%$ ( $\mathrm{SE}=2.3$ ), and $6.9 \%$ ( $\mathrm{SE}=1.8$ ) of the total vascular plant cover, respectively. In FY96, total vascular plant cover on 1986 reclamation sites was an average of $82.4 \%(\mathrm{SE}=2.4)$ of the total cover observed on adjacent undisturbed sites. Fifty-seven, or $86.4 \%$, of the sites were considered successfully reclaimed. Evidence of herbivory was found on $98.5 \%$ of the sites. 
Small mammal burrows were observed on $97 \%$ of the sites. Predator dens or potential dens were observed on $12.1 \%$ of the sites. Lagomorph, rodent, kit fox, and coyote scat were observed at $100 \%, 98.5 \%, 4.5 \%$, and $31.8 \%$ of the sites, respectively. Lagomorphs, coyotes, quail, other birds, and other animals were directly observed at $12.1 \%, 3.0 \%, 4.5 \%, 7.6 \%$, and $4.5 \%$ of the sites, respectively. 
Table 14. Cover and frequency of wildlife and their sign observed on reclaimed sites ten years after reclamation at Naval Petroleum Reserve No. 1, Kern County, California.

\begin{tabular}{|c|c|c|}
\hline \multirow{2}{*}{$\begin{array}{l}\text { Habitat Reclamation Site } \\
\text { Characteristics }\end{array}$} & \multicolumn{2}{|c|}{ Year Reclaimed } \\
\hline & $1985^{a}$ & $1986^{b}$ \\
\hline \multicolumn{3}{|l|}{ Cover $(\%)$} \\
\hline $\begin{array}{l}\text { Total Vascular Plant Cover } \\
\quad \text { Shrubs } \\
\quad \text { Grasses } \\
\quad \text { Forbs } \\
\text { Litter } \\
\text { Bare ground } \\
\text { Adjacent undisturbed } \\
\end{array}$ & $\begin{array}{c}63.1 \\
26.4 \\
45.6 \\
27.8 \\
8.0 \\
29.1 \\
76.9 \\
\end{array}$ & $\begin{array}{c}63.4 \\
21.5 \\
71.7 \\
6.9 \\
6.2 \\
30.6 \\
82.4\end{array}$ \\
\hline \multicolumn{3}{|c|}{ Frequency $^{\mathrm{d}}$ of Wildlife and their Sign (\%) } \\
\hline 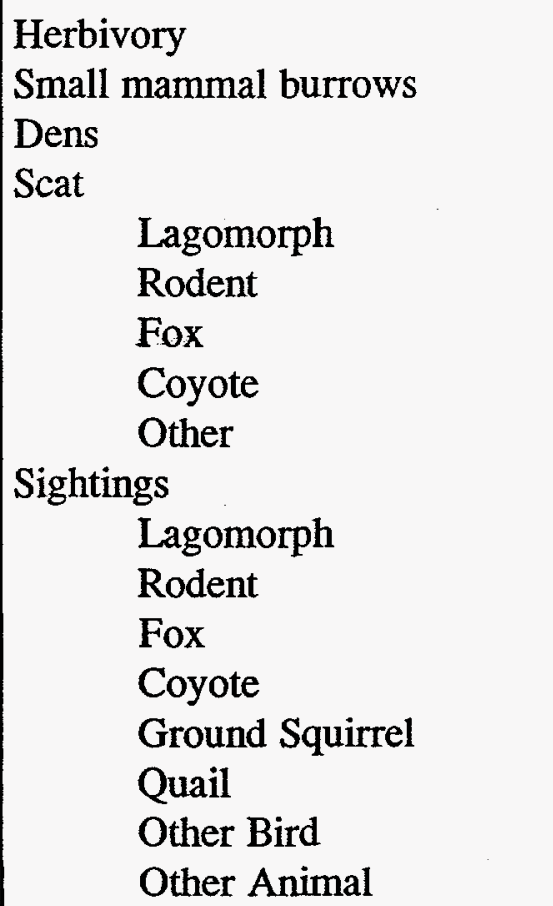 & $\begin{array}{c}94.0 \\
100.0 \\
0 \\
\\
92.0 \\
92.0 \\
0 \\
18.0 \\
0 \\
\\
2.0 \\
2.0 \\
0 \\
2.0 \\
0 \\
16.0 \\
2.0 \\
2.0\end{array}$ & $\begin{array}{c}98.5 \\
97.0 \\
12.1 \\
\\
100.0 \\
98.5 \\
4.5 \\
31.8 \\
0 \\
\\
12.1 \\
0 \\
0 \\
3.0 \\
0 \\
4.5 \\
7.6 \\
4.5\end{array}$ \\
\hline
\end{tabular}

${ }^{2}$ Sites reclaimed in 1985 and sampled in $1995(n=50)$.

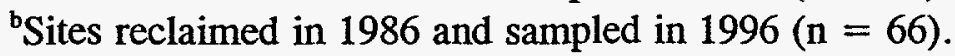

'Percent plant cover on reclamation site divided by percent plant cover on adjacent undisturbed site multiplied by 100 .

${ }^{\mathrm{d}}$ Percent of reclamation sites having wildlife and sign observations. 


\section{CONCLUSIONS}

Vascular plant, bare ground, litter, and percent of adjacent undisturbed cover levels for sites reclaimed in 1986 were similar to levels for sites reclaimed in 1985 , probably due to similar amounts of precipitation received. Most of the sites reclaimed in 1985 and 1986 were pronounced "successfully reclaimed" and will no longer be monitored. The sites exhibited use by wildlife, especially rodents and lagomorphs. Based on the abundant sign, coyotes appear to be utilizing the sites heavily. San Joaquin kit fox scat was recorded on only $4.5 \%$ of the sites. 


\section{RESEARCH AND DEVELOPMENT}

\subsection{FACTORS INFLUENCING THE DISTRIBUTION AND ABUNDANCE OF KIT FOXES ON NPRC}

\section{INTRODUCTION}

Information collected from live-trapping kit foxes is useful not only for determining population size, but it also provides an opportunity for investigating the spatial distribution of these animals. Fox captures have not been evenly distributed over NPRC and the factors underlying the observed spatial patterns are unknown. Therefore, this study was initiated to investigate the effects of variables such as oil field development, topographic ruggedness, and coyote and lagomorph abundance on kit fox distribution. Investigating the distribution and abundance of kit foxes in relation to these variables may yield insight into which habitat features are important for the long term persistence of kit foxes and help determine which features constitute high quality habitat for foxes. Determining the habitat requirements and preferences of foxes may help establish habitat conservation priorities, identify new strategies to enhance habitat for kit foxes, and assess the effects of oil field development and other land uses on kit foxes.

\section{METHODS}

One live-trap was placed in each quarter section during winter (November-January) from 1981 to 1995 to monitor fox populations (Section 2.1). Capture rates of kit foxes were determined by summing the number of adult foxes captured per trapsite. In cases where kit foxes visited a trapsite (fresh scat or tracks) but no foxes were captured, a value of one fox capture was assigned to that site.

The size of the study area changed over the 15-year period. The NPR-1 study area was first trapped in 1981 and it encompassed approximately 11,500 ha. In 1988, the trapping area was enlarged to encompass $96 \%$ of NPRC and the area stayed this size $(31,400 \mathrm{ha})$ for the remainder of the study. To avoid possible confounding effects of changing the size of the trapping area, analyses of kit fox distribution patterns were assessed on the NPR-1 study area through the entire 15-year period. Analyses were performed on the NPRC study area from 1988-1995 to investigate the factors affecting the spatial distribution of foxes on a much larger and diverse area.

Four time periods were defined based on the distribution and status of the kit fox population. The 1981-1982 period represented a time in which kit foxes were fairly evenly distributed throughout the NPR-1 study area and were at relatively high densities. During 1983-1987, the fox population had declined to a much lower level than in 1981-1982 and few foxes were captured in the more rugged terrain. The fox population declined further from 1988-1991 and in 1991 reached its lowest level in 15 years. The fox population increased rapidly during most of the 1992-1995 period. 
Coyote abundance was indexed each spring (February-March) from 1989-1996 on 20 scent station lines (see Section 2.3). For quarter sections with scent stations, the number of coyote visits/number of operable stations $\times 100$ was used to index coyote abundance. Data collected on coyotes (in the spring) were closest in time to data collected on kit foxes (in the winter). Therefore, scent station data from spring 1989-1992 and spring 1993-1996 were used for the 1988-1991 and 1992-1995 time periods, respectively.

Bobcats were incidentally captured while trapping for kit foxes and visits by this species were also recorded during scent station surveys. Locations of captures and locations of bobcat visits to scent stations were plotted on maps to detect patterns of habitat use by bobcats and to compare with the distribution of kit foxes.

Lagomorph abundance was indexed in summer (May-June) on 1.6-km transect lines in 78 quarter sections (see Section 2.4). The number of lagomorphs seen while walking each transect was recorded and used to index lagomorph abundance for the 1988-1991 and 1992-1995 time periods.

The percentage of land area affected by oil field development was calculated for each quarter section of NPRC by overlaying transparent dot grids on 1:10,000 scale aerial photographs taken in 1983 and 1988. Development levels calculated using 1983 photographs were used for analyses involving 1981-1987 data and development levels estimated from 1988 photographs were used for 1988-1995 data.

An index of topographic ruggedness was calculated by measuring the length of contour lines within each quarter section on a 7.5 minute map. Because contour line intervals varied between some maps, a conversion factor was used to make the measurements consistent.

The proportion of each quarter section that was inside the NPR-1 security fence was determined. It was hypothesized that the security regulations which prohibited public access to the site may have indirectly contributed to higher coyote populations. Also, the fence generally divides the area into grazed and ungrazed areas. Grazing by livestock has been prohibited since the 1960s on NPR-1, but most of the surrounding area is grazed by sheep in the spring. Trespass grazing occasionally occurs within the fenced area near the perimeter but most of the fenced area has had little or no grazing for over 20 years. A quarter section was considered to be within the fenced area if more than $50 \%$ of its area was inside the fence.

The percentage of each quarter section burned was determined by reviewing aerial photographs and files of the Kern County Fire Department. Areas that burned between 1975 and 1995 were plotted on maps. Fires may have a short term effect on herbaceous cover, but have the longer term effect of reducing saltbush cover which lasts for a decade or more following a fire. Each quarter section that was burned was considered to have the effect of reduced shrub cover for 10 years. Quarter sections were defined as burned if $50 \%$ or more of the quarter section had burned in the last 10 years. Quarter sections of land that had less than $50 \%$ of the land area burned in the last 10 years were classified as unburned. Quarter sections classified as burned were given 
a score that varied with the number of years in the time period in which there was a burn effect. For example, for the time period 1992-1995, a quarter section that had not burned until 1995 was given a score of one because the quarter section was affected by the burn during one of four years. With respect to the 1992-1995 time period, a quarter section that last burned in 1989 was given a score of four because it was affected for all four years by reduced shrub cover.

Multiple regression was used to model the relationships between counts of each animal species (kit foxes, lagomorphs, and coyotes) and four independent variables (ruggedness, development, burning, fence). The square-root transformation was used on each dependent variable to normalize the residual distributions. Patterns of habitat use were then compared between the three species. Simple linear regression was used to determine if significant correlations existed between the spatial abundance of kit foxes, coyotes, and rabbits.

Models of kit fox abundance were obtained for the NPR-1 study area for all time periods. Also obtained were models of kit fox, coyote, and lagomorph abundance for the NPRC study area in 1988-1991 and 1992-1995. Because of sample size limitations, we did not model lagomorph and coyote abundance on the NPR-1 study area. Results were considered statistically significant at $p \leq 0.05$.

\section{RESULTS}

Spatial distributions of kit foxes were based on 1,760 captures of 1,027 individuals from 19811995. Kit foxes were widely distributed on the NPR-1 study area in 1981 and 1982 . However, by 1983 , fox capture rates decreased markedly in the central and northeastern portions of the study area. As of 1995, kit foxes had not re-occupied this area. From 1988-1995, kit foxes appeared to be most abundant along the perimeter of NPR-1 and in much of NPR-2, but were nearly absent from the interior of NPR-1.

Between 1988-1995, the distribution of 1,494 lagomorph observations, 145 coyote visits to scentstations, and 24 bobcat captures or visits to scent stations was examined. Lagomorphs were most abundant in the central and southern portions of NPR-2 and southeastern NPR-1, and least abundant in the northwestern portions of NPR-2 and NPR-1. Coyotes were widely distributed throughout the reserves, but the highest indices occurred within the interior of NPR-1. Almost all bobcat captures and visits to scent stations were within the interior of NPR-1.

Multiple regression models explained 36 to $60 \%$ of the variation in kit fox capture rates except during 1981-1982, when only $6 \%$ of the variation in capture rates was explained. Correlation between independent variables was low $(r<0.53)$ except between fence and ruggedness on the NPR-1 study area $(r=0.67)$. When fence and ruggedness were both in the model, ruggedness was a significant variable three times as often as fence. Therefore, fence was not included in the final models of the NPR-1 study area because of its high correlation with ruggedness and because it was a less significant variable than ruggedness. 
Kit fox capture rates were negatively associated with ruggedness during all comparisons. Capture rates were negatively associated with development on the NPR-1 study area during 1988-1991 and 1992-1995 and on the NPRC study area during 1992-1995. However, a positive association between fox capture rates and development was almost significant $(p=0.07)$ in 1981-1982. Capture rates were positively associated with burning on the NPR-1 study area during 1983-1987, 1988-1991, and 1992-1995 and on the NPRC study area during 1992-1995. Fox capture rates were negatively associated with the fence variable on the NPRC study area.

Regression models explained 24 to $34 \%$ and 4 to $10 \%$ of the variation in lagomorph and coyote indices, respectively. Lagomorph counts were negatively associated with burning during both time periods. Lagomorph counts were also positively associated with development during the 1992-1995 time period. Coyote indices were positively associated with fence during both time periods. No other variables explained a significant proportion of the variance in coyote visitation indices.

Fox capture rates were negatively correlated with coyote indices during the 1992-1995 time period $(r=-0.22 ; 132 \mathrm{df} ; p=0.01)$ but the two variables were not correlated during the 1988-1991 time period ( $r=-0.08 ; 132 \mathrm{df} ; p=0.34$ ). Capture rates of kit foxes were not significantly correlated with lagomorph counts during the 1988-1991 period $(r=-0.10$; $77 \mathrm{df} ; p=0.37)$ or the 19921995 period $(r=0.15 ; 77 \mathrm{df} ; p=0.18)$.

\section{CONCLUSIONS}

Topographic ruggedness was the only consistent variable affecting the spatial distribution of foxes on NPRC. This is not surprising given that kit foxes are usually found in areas of relatively flat terrain. However, gentle terrain is not a strict habitat requirement of kit foxes. Kit foxes occupied the relatively steep areas of NPR-1 in 1981 and 1982, and kit foxes are known to inhabit or travel through relatively steep terrain in California and Nevada. Although kit foxes have the ability to occupy areas of steep terrain, these areas may be somewhat marginal in quality and kit fox numbers may decline more rapidly in these areas when the population is stressed.

Fence was the most important variable explaining fox distribution on the NPRC study area. The area outside the security fence was usually grazed by sheep in the spring and access by the public was not controlled. However, these factors probably did not have a direct influence on patterns of kit fox distribution. The limited grazing by sheep each spring seemed to have little effect on the vegetation or prey base and there have been few instances of people harassing or killing kit foxes. Instead, the strong negative influence exerted by this variable (with respect to fox capture rates) may be related to higher predator abundance within the fenced area. Coyote indices were positively associated with fence when the entire area was modeled and almost all bobcat captures and visits to scent stations were inside the fenced area. Coyotes and/or bobcats are significant sources of kit fox mortality on NPRC and other areas. Higher predator densities in combination with the rugged terrain in the interior portion of NPR-1 may explain the relative absence of kit foxes in this area. 
The positive association between kit fox capture rates and burning did not seem to be directly related to the abundance of prey. In contrast to fox capture rates, lagomorph counts were negatively associated with burning. Although small mammal abundance was not measured (another important food source), previous data collected on burned and unburned areas of NPR-1 indicated few significant differences in small mammal numbers. The higher capture rates of foxes within burned areas may be related to their interactions with the larger predators. Kit foxes may prefer more open habitats because they are better able to detect coyotes and bobcats in these areas. Also, burning may reduce the habitat quality for larger predators by reducing lagomorph numbers and shrub cover. Lagomorphs are the primary prey of coyotes on NPR-1 and bobcats in the western United States. For bobcats, topographic or shrub cover provides concealment for stalking or ambushing prey, and protection from weather and other predators. The resulting loss in shrub cover after a large fire may make the habitat less suitable for bobcats, especially if the area offers little topographic cover. The apparent preference by kit foxes for burned areas of NPRC may be a result of their ability to avoid larger predators and their ability to exploit areas that are less suitable for bobcats or coyotes.

Capture rates of foxes tended to be negatively associated with oil field development after 1987. Risks to kit foxes from oil field development include human disturbance, increased mortality from vehicles, burying, entrapment in sumps or oil spills, ingestion of contaminants, and loss of habitat or den sites. However, most of these factors have probably had a minor effect on kit fox distribution on NPRC. The presence of kit foxes in the developed areas of NPR-1 in the early 1980s, developed areas of NPR-2, other oil fields more intensively developed than NPRC, and urban areas suggests that this species can adapt to human disturbances. Direct mortality due to oil field activities is rare and results from a toxicology study provided no evidence that oil field chemicals caused kit foxes to decline in developed areas. Also, because of protection programs, den loss on NPR-1 due to development has been minor. Changes to habitat or direct loss of habitat seem to be the most likely explanations for a negative association between fox capture rates and development. A total of 89 quarter sections $(5,763 \mathrm{ha})$ had over $25 \%$ of the land area developed. In these areas the overall carrying capacity for kit foxes was probably reduced. Vegetative changes that accompany development may also affect the spatial distribution of kit foxes. The moderate level of development on NPRC tends to encourage dense stands of saltbush, especially along pipelines, edges of roads, and sumps. The increased saltbush density associated with oil field development may have a detrimental affect on kit foxes, especially when larger predators are abundant.

The relationship between kit fox capture rates and oil field development was not consistent and during 1981-1982, there was a nearly significant positive relationship between the two variables. The unique conditions that occurred in 1981-1982 probably contributed to a positive association between fox capture rates and development. During this time, lagomorphs were at very high levels and more lagomorphs were seen during road surveys within the developed areas than undeveloped areas. Perhaps equally important was the observation that coyotes may have been at relatively low numbers around this time period. During a survey of NPR-1 in 1979, only eight observations of coyotes were recorded, whereas during a similar survey in 1984108 observations 
were recorded. The relatively low number of coyotes in the early 1980s may have allowed kit foxes to exploit abundant prey within the hilly developed regions of the NPR-1 study area without suffering high rates of mortality from coyotes. Indeed, between 1980-1982, mortality rates of kit foxes were often significantly lower than rates after 1982.

The relationship between larger predators and kit foxes appears to be relatively complex. Coyotes occur in most areas that have abundant populations of kit foxes and there are probably adaptations that facilitate coexistence between the two species. However, predation risk may still be a powerful influence on the distribution of kit foxes in some areas. A high risk of predation from coyotes and bobcats may have been an important factor in the decline of kit foxes from the interior of NPR-1. The ability of kit foxes to avoid predation is probably a function of the number of larger predators as well as habitat features that directly affect both predator detection and mobility of kit foxes and their predators. Therefore, it is likely that larger predators and kit foxes can coexist but this relationship is likely dependent on habitat structure and the overall density of the larger predators.

\subsection{CONSERVATION PLAN FOR PROTECTED SPECIES ON NPR-1}

NPR-1 is an active oil and natural gas field, producing approximately 61,000 barrels of crude oil and 330 million cubic feet of natural gas per day. Production on this scale requires a well developed road system, large processing and storage facilities, and numerous support buildings. The resultant disturbance to land surfaces can be considerable in some areas. Nevertheless, the NPR-1 environment supports populations of many vertebrate and plant species. Included among these are several species protected under the ESA. Adequate conservation of protected plant and animal species is facilitated by a comprehensive management plan. Two such plans have been previously prepared for NPR-1, one in 1963 and one in 1987. In 1996, a draft Conservation Plan was prepared for protected species on NPR-1, based on the framework established by the 1987 wildlife management plan. Specific objectives of the Conservation Plan were to: (1) document past and current strategies employed on NPR-1 for conserving protected species, (2) describe the policies and methods by which plan objectives are achieved, and (3) describe future strategies for continued conservation of protected species.

The primary purpose of past and current species conservation strategies was to ensure compliance with terms and conditions expressed in Biological Opinions rendered by FWS in 1980 and 1987 for NPR-1 activities. Secondary purposes of these strategies were to further conserve or enhance threatened and endangered species on NPR-1, to obtain additional information on the natural history of listed species, and to evaluate the potential benefit of conservation strategies. Where possible, conservation strategies were consistent with region-wide species recovery efforts. Past and current conservation strategies have focused on five activities: monitoring of wildlife populations, mitigating loss of habitat, conducting special studies, enforcing operational guidelines and policies, and conducting information transfer and outreach activities. 
The objective of population monitoring is to assess the effects of oilfield developments and fluctuating environmental factors on listed species. The population monitoring program includes the following activities: kit fox population monitoring, giant kangaroo rat population monitoring, blunt-nosed leopard lizard population monitoring, Hoover's wooly-star population monitoring, monitoring of climatic trends, and special status plant monitoring.

The objective of mitigating loss of habitat is to compensate for the permanent and temporary disturbance of native habitats through oilfield developments. The two primary activities used to mitigate loss of habitat are preactivity surveys and habitat reclamation. Preactivity surveys aim to minimize direct impacts of construction projects to protected species by identifying and resolving potential conflicts before development activities begin. Habitat reclamation aims to restore disturbed lands, as closely as possible, to pre-disturbance conditions.

The objective of conducting special studies is to gather basic biological and ecological information on species, and to evaluate the effectiveness of a variety of population and habitat management techniques on the abundance of protected species. Such studies have included assessing well blowout effects on biota, toxicology studies, effects of habitat manipulations on small mammals, effects of disturbance on Hoover's wooly-star, efficacy of supplemental feeding and relocation of kit foxes, and factors affecting kit fox distribution and abundance.

NPRC has adopted a number of policies to protect listed species. Those policies include traffic control, fire suppression, public access control, and employee education. Finally, NPRC sponsors an extensive information transfer and outreach program. Program activities include dissemination of technical information through scientific publications and presentations in region conservation planning efforts, and public outreach including participation in environmental education programs and visiting classrooms. 


\section{PROGRAM ASSISTANCE}

\subsection{PROGRAM SUPPORT}

A primary objective of the NPRC ESCRP is to provide the expert advice, guidance, and assistance necessary for DOE/NPRC compliance with the ESA of 1973 (as amended), NEPA, NHPA, and other laws protecting cultural and historic resources. Other objectives include providing technical and management progress reports, presenting and publishing scientific findings, and engaging in information transfer and educational outreach activities.

Support of specific compliance procedures pursuant to the ESA, NEPA, and NHPA and other cultural resource laws was accomplished through preparing the necessary documentation and supporting consultations as required by these laws. Early in FY96 the formal Section 7 consultation between DOE/NPRC and FWS for continuing oil and gas operations at NPR-1 was completed, and technical support for the evaluation of requirements under the new Biological Opinion issued was provided to DOE/NPRC. In addition to supporting the programmatic consultation, additional consultations were conducted for specific projects on NPRC (see Section 3.2). For historic and cultural resources compliance activities, see section 3.4.

Throughout FY96, the ESCRP provided programmatic management support through a number of activities. These activities included the preparation of weekly coordination summaries, quarterly progress reports, annual scope of work, and detailed project plans. Written input was provided to NPRC's annual Environmental Site Report, Annual Report of Operations, Long Range Plan, and Quarterly Report. EASI staff participated in an operational appraisal of DOE/NPRC's administration of the NPRC ESCRP and provided support as requested by DOE/NPRC for a program evaluation conducted by DOE headquarters. Also, a procedure self-assessment was conducted on scent station surveys by EASI staff.

Numerous articles for the Elk Hills Weekly were drafted and provided to DOE/NPRC. EASI staff members attended weekly environmental coordination meetings, DOE/NPRC Technical Assurance Branch staff meetings, and NPR-1 3-D seismic program meetings. Briefings were provided to NPRC management on the annual scope of work, project progress, and related compliance issues. EASI staff participated in site and program overviews to FWS staff from the Sacramento Field Office who were here to learn more about operations at NPRC and the Endangered Species Program.

Scientific findings based on work performed by the Endangered Species and Cultural Resources Program at NPRC were presented at various forums, including Endangered Species Advisory Committee meetings, professional society meetings, and at an Annual Program Review attended by approximately 85 people from various federal and state agencies, oil and gas companies, and other interested organizations. EASI also attended meetings sponsored by the San Joaquin Valley Endangered Species Recovery Planning Program (SJVESRPP), BLM, Kern County Valley Floor 
Habitat Conservation Plan Committee, and the Lokern Natural Area Management Program to provide these groups with the information and experience gained through the ESCRP at Elk Hills.

Numerous educational outreach activities were conducted throughout the year. EASI staff provided training in handling kit fox pups to staff from the SJVESRPP and provided assistance to SJVESRPP biologists with live-trapping and radiocollaring kit foxes in the Panoche Hills located in the northwestern portion of the San Joaquin valley. Five teachers participating in the Taft City School District Mentor-Science Program accompanied EASI biologists in the field to observe kit fox trapping activities. A Bakersfield elementary school teacher visited NPRC to observe EASI giant kangaroo rat trapping efforts. EASI assisted with an investigation of carnivore DNA identification by contributing samples of kit fox scat and hair to a doctoral student at the University of California at Davis.

On-site tours and briefings also were given to a variety of persons and groups. EASI staff hosted an informal visit and site tour for individuals from the Los Alamos National Laboratory (LANL) Environmental Program. An oil neststraw identification workshop for field biologists was conducted by EASI staff in Bakersfield. The purpose of the workshop was to help other field biologists operating off-site identify occurrences of oil neststraw.

EASI made significant contributions to NPRC's annual Earth Day activities held both on-site and at the California State University, Bakersfield campus by providing educational booths, displays, activities for visiting school children, and coordinating booths and displays from off-site organizations. Two Project WILD training sessions were conducted by the EASI Project WILD facilitators. One training session was geared for volunteers at the Coles Levee Ecosystem Preserve, and another was for five local elementary and junior high school teachers. EASI staff members participated in the Derricks to Desks program, sponsored by local industry to inform teachers about oil field operations. Staff also participated in several presentations at the Coles Levee Ecosystem Preserve in cooperation with staff from ARCO Western Energy, CDFG, and private environmental and cultural resources consultants. EASI staff participated in several classroom visits to local schools to present information about endangered species, and an EASI staff member gave presentations to two Bakersfield eighth grade language arts classes about wolves in preparation for their intensive study of The Call of the Wild. In addition to judging science fairs at local schools and for the Kern County Science Fair, several EASI staff members participated in DOE/NPRC's Science Bowl by volunteering their time as coaches and moderators. Three animal specimens salvaged by EASI staff at Elk Hills were transferred to the California Museum of Science and Industry in Los Angeles.

\subsection{PROJECT DOCUMENTATION}

Research conducted by the NPRC Endangered Species and Cultural Resources Program has resulted in the generation of numerous data of value to regional as well as on-site conservation efforts. In FY94, an effort was initiated to examine existing data collected at NPRC, analyze this 
data, and prepare manuscripts for submission to scientific outlets for publication. Several manuscripts were completed in FY96 and submitted to journals for publication, and significant progress was made on the preparation of several other papers.

During 1982 to 1984, data were collected on movements and home range patterns of radiocollared blunt-nosed leopard lizards. Some of these data were presented in a topical report published in 1987. In FY95, these data were reanalyzed to more thoroughly examine home range, movement, and habitat use patterns of blunt-nosed leopard lizards relative to habitat conditions, particularly vegetative cover. In FY96, a manuscript was completed and submitted to the Journal of Herpetology for consideration for publication.

Since 1980, data on den use patterns of radiocollared kit foxes have been collected at NPRC. These data were analyzed in FY96, and a manuscript has been completed and submitted to the Journal of Wildlife Management for consideration for publication.

Another manuscript completed in FY96 addressed competitive interactions between coyotes and kit foxes. This paper quantifies both interference and exploitation competition between these two species, and discusses implications of the results for kit fox conservation. This manuscript has been submitted to the Journal of Mammalogy for consideration for publication.

Significant progress was made in FY96 on two other manuscripts. One paper addresses the effective population size of kit foxes at NPRC and the other describes aspects of the social ecology of kit foxes. Both manuscripts will be completed in FY97 and submitted for publication.

In addition to completing the manuscripts above, additional manuscripts to be completed in FY97 include a monograph-length manuscript describing kit fox population dynamics at NPRC from 1980-1995, an assessment of factors influencing habitat reclamation success, and an analysis of small mammal community composition dynamics based on data collected during extensive trapping efforts conducted from 1980-1984. 


\section{PUBLICATIONS}

In FY96, a number of scientific manuscripts and technical reports were published or accepted for publication. These are listed below.

\section{Published documents include:}

Anderson, D. C. 1995. Habitat reclamation plan to mitigate for the loss of habitat due to oil and gas production activities under Maximum Efficient Rate, Naval Petroleum Reserve No. 1, Kern County, California. U. S. Department of Energy Topical Report. EG\&G/EM Report No. 11265-1115. 44 pp.

Anderson, D. C., and G. L. Holmstead. 1995. Characterization of Eriastrum hooveri (Hoover's wooly-star) habitat on the Naval Petroleum Reserves in California. U. S. Department of Energy Topical Report. EG\&G/EM Report No. 11265-1167. 39 pp.

Cypher, B. L. 1995. Influence of physiography and vegetation on small mammals at the Naval Petroleum Reserves, California. Transactions of the Western Section of the Wildlife Society $31: 45-52$.

Cypher, B. L. 1995. Coyote morphometric characteristics and mass dynamics in the San Joaquin Valley, California. The Southwestern Naturalist 40:32-37.

Cypher, B. L., and J. H. Scrivner. 1996. Summary of coyote data collected at the Naval Petroleum Reserves in California. U. S. Department of Energy Topical Report. EG\&G/EM Report No. 11265-2005. 20 pp. + appendices.

EG\&G Energy Measurements, Inc. 1995. Endangered Species Program Naval Petroleum Reserves in California Annual Report FY94. U. S. Department of Energy Topical Report. EG\&G/EM Report No. EGG 11265-1162. 59 pp.

EG\&G Energy Measurements, Inc. 1996. Endangered Species Program Naval Petroleum Reserves in California Annual Report FY95. U. S. Department of Energy Topical Report. $62 \mathrm{pp}$.

Kaplan, I., S. Lu, R. Lee, and G. Warrick. 1996. Polycyclic hydrocarbon biomarkers confirm selective incorporation of petroleum in soil and kangaroo rat liver samples near oil well blowout site in the western San Joaquin Valley, California. Environmental Toxicology and Chemistry 15:696-707. 
Scrivner, J. H., and B. L. Cypher. 1993. Summary and evaluation of the coyote control program, Naval Petroleum Reserves in California, Kern County, 1985-1990. U. S. Department of Energy Topical Report. EG\&G/EM Report No. 10617-2140. 46 pp.

Documents in press include:

Cypher, B. L. Effects of radiocollars on San Joaquin kit foxes. Journal of Wildlife Management.

Cypher, B. L., K. A. Spencer, and J. H. Scrivner. Food item use by coyote sex and age classes. California Fish and Game Journal.

Holmstead, G. L., and D. C. Anderson. Reestablishment of Hoover's wooly-star (Eriastrum hooveri) following disturbance. Madroño.

Otten, M. R. M., and B. L. Cypher. Conservation plan for protected species on Naval Petroleum Reserve No. 1, Kern County, California. U. S. Department of Energy Topical Report. EASI Report No. 1997-1. 39 pp. + appendices.

Otten, M. R. M., and G. L. Holmstead. Effects of seeding burned lands on the abundance of rodents and leporids on Naval Petroleum Reserve No. 1, Kern County, California. The Southwestern Naturalist. 


\section{DISTRIBUTION}

U. S. Department of Energy, Naval Petroleum Reserves in California

Tupman, California

J. Williams, Director (2)

W. Kauffman

J. Killen

D. Ellison

G. Walker

U. S. Department of Energy, Office of Naval Petroleum and Oil Shale Reserves

Washington, D. C.

E. Hunter

D. Silawsky

U. S. Department of Energy, Headquarters

Oak Ridge, Tennessee

OSTI (2)

U. S. Department of the Interior, Bureau of Land Management

Bakersfield, California

L. Saslaw

A. Kuritsubo

U. S. Department of the Interior, Fish and Wildlife Service Portland, Oregon
A. Banks

J. Bartel
U. S. Department of the Interior, Fish and Wildlife Service Sacramento, California

H. Bell

P. Cross

J. Knight

J. Medlin

U. S. Department of the Interior, Fish and Wildlife Service, Kern National Wildlife Service Delano, California

J. Allen

U. S. Department of the Interior, U. S. Geologic Survey San Simeon, California

G. Rathbun

U. S. Forest Service Goleta, California

B. Peckham

ARCO Western Energy Bakersfield, California

S. Geddes

Bechtel Petroleum Operations, Inc. Tupman, California

G. Emsurak (2)

B. Dixon

G. Gough 
California Department of Fish and Game

Fresno, California

R. Reed

J. Single
Cal Poly-Camp Roberts

Camp Roberts, California

P.J. White 